\title{
Developing Historical Competency: Teaching German History Through History Films At University Putra Malaysia
} (BA German Programme)

http://dx.doi.org/10.11606/1982-8837254529

\author{
Torsten Schaar ${ }^{1}$ \\ Chang Shi Wen ${ }^{2}$
}

\begin{abstract}
History films personalize, dramatize and emotionalize historical events and characters. They revive the past by exemplifying it in the present, engage ongoing discourses of history and as a result have proven to be the most influential medium in conveying history to large audiences. History films are regarded as an attractive, motivating and efficient (supplementary) teaching and learning medium in history as well as in foreign language classes. As part of the course "Historical Survey of Germany" (BA German-programme at University Putra Malaysia) history film projects on important periods and events in German history were conducted. The article introduces a film project on World War II and describes the pedagogical approach which aims to develop three core competencies of historical understanding - Content Knowledge, Historical Empathy/Perspective Recognition and Narrative Analysis. It discusses selected general findings provided as qualitative data in group and individual assignments. While the responses to questions related to Content Knowledge and Narrative Analysis show that students achieved higher competency levels, the participants showed shortcomings in the rational examination of historical characters, their perspectives and motivations for their actions. Time, practice and guidance can be identified as key factors in developing historical literacy competencies further.
\end{abstract}

Keywords: BA German programme; German history (20th century); history film project; historical literacy competencies; University Putra Malaysia.

\footnotetext{
${ }^{1}$ German Jordanian University, School of Applied Humanities and Languages, Amman, Jordan. E-mail: torstenschaar@web.de. ORCID: 0000-0003-1651-8210

${ }^{2}$ University Putra Malaysia, Faculty of Modern Languages and Communication, Serdang, Malaysia. Email: xantthe@gmail.com. ORCID: 0000-0002-3883-1307
}

\section{(cc) BY-NC}


SCHAAR, T.; WEN, C.S. - Developing Historical Competency

\section{Teaching German History at University Putra Malaysia}

Developing critical thinking and information literacy skills through the use of film in the classroom rank among our most important tasks as historical educators in the twenty-first century ... (BYERS 2010)

History is officially regarded as an essential part of the education process of young Malaysians "because it is intimately related to the development of nation building, citizenship and national integration" (JohDi SALLEH; MoHAmAD; AmBOtANG 2013: 2). The current history curriculum (introduced in 1989 and based on curricula used in the United Kingdom) takes the previous divide of the multi-ethnic Malaysian society and the lessons learned from the deadly $13^{\text {th }}$ May 1969 incident (Sino-Malay sectarian violent riots causing hundreds of deaths) into consideration. Therefore, it primarily focusses on the contribution of the people of Malaysia throughout the centuries in order to "raise consciousness about the reality of the multiethnic-based politics, economics, social and cultural practices of the country" (JoHDi SALLEH; MoHAMAD; AMBOTANG 2013: 2). ${ }^{3}$ Furthermore, the curriculum aims to develop students' critical thinking skills and an understanding of complex topics about humans and societies, their ability to interpret history, to solve problems, to practise communication skills and extend vocabulary, to use historical sources as well as strengthen their self-confidence and pride of being Malaysian. ${ }^{4}$ Chong and Yeo analysing the issue "Why Malaysian Students Fail in History", however, pointed out that the importance of this academic subject "has always been overlooked by the young generation" (2016: 517). According to quoted surveys, history is considered by many Malaysian secondary school students to be of limited usefulness, a tedious and boring subject without any commercial value (2016: 517). Johdi Salleh, Mohamad and Ambotang added that despite the important step of the inclusion of history as a core subject in the Integrated Curriculum for Secondary School (ICSS) “...some people underestimate this subject, especially when Malaysia is busy in the development of sophisticated technology and Multimedia Super Corridor (MSC) projects" (2013: 8). Chong and Yeo pay special attention

\footnotetext{
${ }^{3}$ Consistent with the educational objectives of Malaysia, history is included in the curricula of the country's ordinary, science, vocational, technical and religious schools and has become a compulsory pass subject in secondary schools (since 2013) to obtain the Malaysian Certificate of Education (a national examination taken by 'secondary five' students).

${ }^{4}$ The subject dealing with important issues such as politics, national integration and unity is thus regarded by politicians and educators as "an effective instrument to create national identity, reinforce a sense of belonging and loyalty to the country", as well as "important in the production of motivated and active citizen who can learn effectively and be competent in their future jobs career" (JOHDI SALLEH; MOHAMAD; AMBOTANG 2013: 1).
} 
SCHAAR, T.; WEN, C.S. - Developing Historical Competency

to the short-comings of common teaching practises used in Malaysia's history classrooms - reading and memorizing historical events - and come to the conclusion: "A student might just simply memorize everything from textbooks in a rough-and-tumble way. As a consequence, History becomes an incomprehensive and monotonous subject. Eventually, History appears to be very difficult to learn." (2016: 517).

While learning the German language, students not only acquire linguistic knowledge and the skills and competences to be able to adequately communicate in authentic situations, but also an understanding of cultural contents and its meanings in the German-speaking countries. The present in its socio-cultural context can only be understood "through the inclusion of historical patterns of explanation" (KOREIK 1995: 78). The role of history as an important contributor to the cultural identity of a nation in teaching and learning German as a foreign language was already outlined in the ABCD Theses (developed on a trinational basis) in $1990 .{ }^{5}$ Chudak (2015: 135) stated that a variety of goals can be achieved in intercultural oriented foreign language teaching by dealing with history. Besides the development of foreign language skills, an ensemble of skills and qualities can be trained which are considered the basis of intercultural competence such as sensitivity and empathy, openness, curiosity, tolerance, the ability to observe and to interpret, and the willingness to correlate one's own perspective. Therefore, the focus of teaching history is not only to convey important facts and figures, but the aim is also to provide an insight into historical events that have shaped patterns of thought, identity and behaviour in Germany to this day (see also ARENDT 2019: 341).

The Bachelor of Arts in Foreign Languages (German)-programme (BA German) at Fakulti Bahasa Moden dan Komunikasi (FBMK) / University Putra Malaysia (UPM) - a leading public university in Malaysia - was introduced in the academic year 2000/2001. The curriculum combines German as a foreign language instruction until B2 level (GER), traditional philological subjects (e.g., Linguistics, German Literature) and market-oriented courses (e.g., German for Specific Purposes: Business / Tourism). Table 1 shows the number of students in each cohort without indicating their Malay, Malaysian-

\footnotetext{
${ }^{5}$ Thesis 13 reads: Landeskunde ist in hohem Maße auch Geschichte im Gegenwärtigen. Daher ergibt sich die Notwendigkeit, auch historische Themen und Texte im Deutschunterricht zu behandeln. Solche Texte sollten Aufschluß geben über den Zusammenhang von Vergangenheit, Gegenwart und Zukunft, über unterschiedliche Bewertungen sowie über die Geschichtlichkeit der Bewertung selbst. ["Landeskunde" is to a large extent also history in the present. Therefore, there is a need to include historical topics and texts in German lessons. Such texts should shed light on the link between the past, present and future, via different evaluations and on the historicity of the evaluation itself.] (ABCD THESEN 1990: 17, translated with DeepL.com/Translator).
} 
SCHAAR, T.; WEN, C.S. - Developing Historical Competency

Chinese, Malaysian-Indian or indigenous background. The BA German cohorts 12-15 were being dominated by female students $(86=86 \%)$ with Malay (Muslim) females as the largest ethnic group. ${ }^{6}$ None of the students had professed any previous knowledge of German.

Table 1 - Number of BA German students

\begin{tabular}{|l|c|c|c|c|c|}
\hline Enrolled in academic year - cohort & $\begin{array}{l}2013 / 2014 \\
\text { Cohort 12 }\end{array}$ & $\begin{array}{l}2014 / 2015 \\
\text { Cohort 13 }\end{array}$ & $\begin{array}{l}2015 / 2016 \\
\text { Cohort 14 }\end{array}$ & $\begin{array}{l}2016 / 2017 \\
\text { Cohort 15 }\end{array}$ & \\
\hline Number of students (overall) & 23 & 28 & 21 & 28 & 100 \\
\hline Number of students (female) & 21 & 24 & 17 & 24 & 86 \\
\hline Number of students (male) & 2 & 4 & 4 & 4 & 14 \\
\hline
\end{tabular}

Source: Prepared by the authors

One of the compulsory courses for first year-students in the BA German curriculum is BBD 3101 "Kajian Sejarah Jerman" (Historical Survey of Germany). What challenges do German university lecturers encounter while teaching BA German students the history of the country of the language they are learning? Due to its technology and scientific achievements, Germany has a very positive image in Malaysia and is visible through its modern products (especially cars, sportswear, and luxury food). However, the history of Germany does not have a prominent role in the collective memory of Malaysia since it was not a colonial power in South East Asia und was not directly involved in the events of World War II in British-Malaya.

The course BBD3101 Kajian Sejarah Jerman was taught by the corresponding author from 2002 to 2009 and from 2012 to $2018 .{ }^{7}$ German history from the $8^{\text {th }}$ century to the present time is not just embedded in German language instruction or in German culture and literature courses, as it is a common practice in many university programmes worldwide; it was taught over the period of one academic semester (42 contact hours, 14 weeks), and included course-work, two tests, assignments as well as a written final examination. Besides the unquestionable importance of accumulating factual knowledge (even though it will be superficial), the course aims to develop students' abilities to analyse information, draw conclusions, to critically think and question motives for certain actions; behaviours and developments and as a consequence to overcome stereotypes and

\footnotetext{
${ }^{6}$ The first choice-study-subject of the students enrolled in the BA German programme in the years 2013 to 2016, however, was not the German language but rather a variety of other subjects such as Business Management and Administration, Financial Management, Accounting, Mass Communication, Hospitality \& Tourism, Education, Psychology, Computer Design and other foreign languages such as French or Korean. German language was named by $52 \%$ of the students as one of their eight possible study priorities.

${ }^{7}$ If one compares the BA German curricula in South-East-Asia, it becomes evident that BBD3101 is a unique course since it only focusses on the history of the country of the target language This assumption is based on correspondence with lecturers of German language in East/South-East Asia.
} 
SCHAAR, T.; WEN, C.S. - Developing Historical Competency

prejudices. However, it must be critically noted that BBD3101 follows the concept of the traditional historiography (history of events with a focus on politics, economics, the military, diplomacy). The course description does not take into consideration the paradigm shifts towards a cultural history, the so called "second-degree" historiography (coined by French historian Pierre Nora) which is no longer exclusively concerned with historical facts and events, but also gives attention to the emergence of or changes in collective memories and on the identity-forming functions of memories. (KOREIK; ROCHE 2014: 1011) Also, the course outline completely neglects the concept of "places of remembrance", which has been widely accepted in history and in cultural studies for several decades according to the definitions of Pierre Nora, Françoise/Schulze, Hahn/Traba and others. ${ }^{8}$

What previous knowledge of German history did the students bring to the course? The Malaysian high school history textbooks (Sejarah Tingkatan 4 and 5: 2002) provide only very limited information on German (and European) history on which to build on. Table 2 provides an overview of historical periods and the teaching content:

Table 2 - Teaching content of Malaysian history textbooks

\begin{tabular}{|l|l|}
\hline $\begin{array}{l}\text { Textbook for Grade } 4 \\
\text { War I) }\end{array}$ \\
$\begin{array}{l}16^{\text {th }} 17^{\text {th }} \text { century: Refor- } \\
\text { mation }\end{array}$ & $\begin{array}{l}\text {-Invention of the printing press by Johannes Gutenberg } \\
\text {-Martin Luther's criticism of selling indulgences and his belief that only } \\
\text { God can forgive sins, challenged the church } \\
\text {-Sweden, Norway, England became Protestant countries } \\
\text {-Thirty-Years War between Catholics and Protestants }\end{array}$ \\
\hline $\begin{array}{l}19^{\text {th }} \text { century: } \\
\text { Industrial Revolution }\end{array}$ & $\begin{array}{l}\text {-Germany became one of the leading industrial powers in the world } \\
\text {-Germany as a colonial power in Africa and Asia }\end{array}$ \\
\hline World War I & -brief summary of the events of the war \\
\hline $\begin{array}{l}\text { Textbook for Grade } 5 \\
\text { until present day Malays school (17-year-olds) Sejarah Tingkatan 5 (World War I }\end{array}$ \\
\hline Treaty of Versailles & $\begin{array}{l}\text {-harsh restrictions and penalties being imposed on Germany, which ulti- } \\
\text { mately led to World War II }\end{array}$ \\
\hline Adolf Hitler & $\begin{array}{l}\text {-Hitler's rise to power and the re-armament of Germany to fight economic } \\
\text { depressions and to challenge the powers behind the Treaty of Versailles }\end{array}$ \\
\hline World War II & $\begin{array}{l}\text { Nazi-Germany attacks Poland; England and France declare war on Ger- } \\
\text { many, the USSR attacks Poland as well } \\
\text { Germany was defeated and the war in Europe ended on } 8^{\text {th }} \text { May 1945 }\end{array}$ \\
\hline
\end{tabular}

\footnotetext{
${ }^{8}$ The concept is based on memory theories by Maurice Halbwachs, Aby Warburg and on reflections on communicative and cultural memory by Jan Assmann. It increasingly finds its way into teaching German as a foreign language due to its relevance for cultural learning in foreign-language teaching and its diverse didactic-methodological potential in the teaching of relevant regional history/historical content (see e.g. KOREIK; ROCHE 2014, KOREIK 2015, SCHMIDT; SCHMIDT 2016, BADSTÜBNER-KIZIK 2020).

${ }^{9}$ Malaysia belongs to countries whose curricula refer to the Second World War or to National Socialism, without referring explicitly to the Holocaust (see: UNESCO: The International Status of Education about the Holocaust. A Global Mapping of Textbooks and Curricula, BRAUNSCHWEIG 2015: 36).
}

Pandaemonium, São Paulo, v. 25, n. 45, jan.-abr. 2022, p. 29-65 
SCHAAR, T.; WEN, C.S. - Developing Historical Competency Aftermath of World War Germany was divided into East- and West-Germany II

Source: Sejarah Tingkatan 4 \& 5: 2002

Some material traces of German history in Malaysia ${ }^{10}$ can be found on the island of Penang, one of the country's most popular tourist attractions. In 2012, a German Heritage Trail which highlights 10 historical landmarks was established in George Town to raise awareness to the heritage of the German-speaking community (German Heritage Trail 2012: 8-36, The Star 13.10.2012). However, hardly any of the BA students (even those from Penang) have shown interest in it or were even aware of the existence of the German Heritage Trail.

A lecturer in the course BBD 3101 - which is taught in the second semester - is confronted with the above-described challenges that most Malaysian learners have little interest in history as such, and that they only possess a rudimentary knowledge of German (and European) history. Moreover, their German language skills are at an A2 level and their English language skills are intermediate at B1.2 level (with the occasional exception). The subject, therefore, had to be taught in relatively simple English. Since the educational system of Malaysia is extremely exam-oriented and students strive for good grades, there were hardly any problems with students' absences from classes or their willingness to study. Hence, the main problem from the lecturer's point of view was the passivity of the students in class, which was a result of the above-mentioned teaching practices in Malaysian schools. ${ }^{11}$ To achieve the academic standards of teaching history through actively involving the BA students in the learning process - taking their preference for visualised material into account and to offer them a more emotional approach to

\footnotetext{
${ }^{10}$ In her 2006 publication "More than Merchants", author Khoo Salma Nasution describes and illustrates how Penang Island attracted German and Swiss traders (the second largest European trading community after the British) to conduct business (in close cooperation with the British establishment) and make their fortunes there. German import-export houses traded in European goods, refined tin and agricultural products. Non-traders such as missionaries, administrators, engineers, writers, photographers followed once regular shipping routes between German seaport cities and Penang had been established since 1885. They contributed to engineering (tin smelting and tin refining), postcard publishing, photography and to public life. The architect Henry Alfred Neubronner designed several iconic buildings in George Town. Famous visitors to Penang were the writers Karl May (1899) and Herman Hesse (1911). World War I had severe consequences for the German/Swiss community in Penang. On $28^{\text {th }}$ October 1914, the German light cruiser H.M.S Emden raided the harbour and sank the Russian cruiser "Shemtshug" and the French destroyer "Mousquet". All German nationals had their properties confiscated and were arrested and interned as enemy aliens. Several German companies were publicly auctioned. In World War II, German U-boats operated from the naval base in Penang which was under Japanese occupation (1941-1945) (KHOO 2006).

${ }^{11}$ The teacher narrates and writes on the board (or reads the presentation slides), the students copy, memorize and reproduce the contents for tests and exams. They are not used to ask critical questions, to discuss contents or to draw conclusions independently.
} 
SCHAAR, T.; WEN, C.S. - Developing Historical Competency

history - , the lecturer implemented a mix of teaching methods: A) traditional requirements for narrating the past: excerpts from (history) books, documents, lecturer's presentations supported by visual elements: photographs, pictures, posters, statistics, B) the inclusion of history films ${ }^{12}$ and C) independent research.

The article now focusses on method B and the following research questions:

1. How did the BA German students perceive the implementation of history films and history film projects as teaching tools?

2. Which history films and which historical events have aroused the students' interest?

3. Which historical competencies have been particularly developed through film work or film projects?

\section{History Films as teaching tools - developing historical literacy}

The use of feature films as an attractive, modern, motivating, emotionally appealing and efficient (supplementary) teaching and learning medium in foreign language teaching, its numerous advantages (and also certain disadvantages), the selection criteria and its many didactic applications have been widely researched and described in detail in an almost unmanageable number of publications over the last three decades. Films as teaching tools are particularly suited for young adult learners since they correspond to their natural curiosity and leisure time activities (the everyday use of media which influences their perception of the world). They appeal to their imagination, develop cognitive processes and competences, provoke reactions and promote "real life learning" (see e.g. BIECHELE 2010, BRANDi 1996, FAISTAUER 2010, SCHWERDTFEGER 1989). This applies equally to the role and the great didactic potential of history films (HFs) - especially the mainstream drama ${ }^{13}$ - as powerful teaching tools in history lessons and in foreign language teaching respectively. Well-prepared history classes using HFs not only provide the necessary background knowledge and concepts, develop media literacy, historical competences, and

\footnotetext{
${ }^{12}$ History Film "a film, which evokes and makes meaningful the world of the past" (ROSENSTONE 2012: xi)

${ }^{13}$ Rosenstone distinguishes 3 types of history films a) the mainstream drama / dramatic feature film (incl. tv-movies, series, docudrama) b) the innovative history films c) the compilation documentary (ROSENSTONE 2012: 16) While documentaries are consigned to a marginal status and the innovative history film is hardly recognizable at all, Rosenstone points out: "The dramatic feature film has been and continues to be, in terms of audience and influence, the most important form of history in the visual media." (ROSENSTONE 2012: 17)
}

Pandaemonium, São Paulo, v. 25, n. 45, jan.-abr. 2022, p. 29-65 
SCHAAR, T.; WEN, C.S. - Developing Historical Competency

analytical skills to help and guide students to make sense of the film. They too develop students' abilities to engage in critical thinking about HFs not just as an entertainment product but as a constructed and interpreted "document" of a historical event and/or character(s) which - like a written historical document or text containing content knowledge or interpretation - needs to be discussed, analysed, critiqued and interpreted. HFs help students to recognize multiple perspectives (and missing perspectives), to explain different viewpoints and motives of characters / groups in the past, to distinguish between truth and fiction, as well as to realize how past events shape today's world. (MARCUS; METZGER; PAXTON; STODDARD 2010: 7; 9; 17-18; 25, WOELDERS 2007: 373-381) Furthermore, HFs provide students with authentic opportunities "to apply historical knowledge by comparing, evaluating, and interpreting conflicting ideas and perspectives about how people interpret or experience worlds that no longer exist" (WOELDERS 2007: 146).

HFs are authentic and entertaining art products purposefully created by humans for humans containing a specific message which visualize a (mostly) closed version of the past ${ }^{14}$, using audio-visual "language": location, design, the juxtaposition of images, acting, movement, dialogue semiotics, camerawork (shots, angles, perspectives, speed of framing), costume, colour, editing, music, sound-effects... (ROSENSTONE 2012: 29; 53, DONELLY 2013: 19) The audience sees landscapes, towns, villages, buildings, streets and squares, faces and bodies, clothes, tools and furniture, weapons, implements, "all the material objects to a culture at a given historical period" (RosEnstone 2012: 18). Usually neglected by written academic history, these reality effects add to the feeling of authenticity and are of great importance in contributing to the creation of historical meaning (RosEnSTONE 2012: 19). HFs personalize, dramatize and emotionalize (but also fictionalize) extraordinary historical events. HFs tell enticing stories of documented and/or fictional individuals and/or groups (which might exemplify larger historical events or processes). The language of HFs can elicit strong immediate emotional responses; the feeling not just to witness but to experience victory, valour and happiness but also agony, despair, hopelessness and defeat. (RosEnSTONE 2012: 19; 53, DonELLY 2013: 23; 2014: 7)

... individuals (one, two or a small group) are at the center of the historical process. Through their eyes and lives, adventures and loves, we see strikes, invasions, revolutions, dictatorships, ethnic conflicts, scientific experiments, legal battles, political movements, holocausts. But we do more than see: we feel as well. Using image, music and sound effect along with the spoken (and shouted, whispered, hummed and cooed) word, the dramatic film aims directly at the emotions. It does not simply provide an image of the

\footnotetext{
${ }^{14}$ American mainstream dramas mostly provide a feeling of uplift, while European productions tend to be more open to tragic or sad endings. (ROSENSTONE 2012: 53; 58)
}

Pandaemonium, São Paulo, v. 25, n. 45, jan.-abr. 2022, p. 29-65 
SCHAAR, T.; WEN, C.S. - Developing Historical Competency

past, it wants you to feel strongly about that image - specifically about the characters involved in the historical situations that it depicts. Portraying the world in the present tense, the dramatic feature plunges you into the middle of history, attempting to destroy the distance between you and the past and to obliterate - at least while you are watching - your ability to think about what you are seeing. Film does more than want to teach the lesson that history hurts; it wants you, the viewer, to experience the hurt (and the pleasures) of the past. (ROSENSTONE 2012: 18)

HFs speak "in a language that is metaphorical and symbolic, a language that creates a series of proximate or possible realities rather than a reality that is literally true" (ROSENSTONE 2012: 54). With their unique interpretation of "historical truth" and engaging in historical discourse HFs undoubtedly contribute to the understanding of the past, and decisively influence the culture of remembrance. HFs have proven to be the most successful medium in conveying history to large audiences and have even replaced classical historiography. (see e.g. SCHAAR 2015: 136, FRÖHLICH; SCHNEIDER; VISARIUS 2007:

\section{7-12, BYERS 2010)}

Each day it becomes clearer to even the most academic of historians that the visual media are the chief conveyor of public history in our culture. That for every person who reads a book a historical topic about which a film has been made ... many millions of people are likely to encounter the same past on the screen. (ROSENSTONE 2012: 14)

The focus of the film-based instruction in class was the development of historical literacy competencies as part of media education / media literacy ${ }^{15}$ which Bellino defines as "a lifelong 'thinking disposition' that facilitates critical consumption and inquiry of all media forms in all consumption contexts" (2008: 4-5). Metzger (2007) nominated 5 important historical literacy competencies (HLC) - Content Knowledge (CK), Narrative Analysis (NA), Historical Empathy (HE) as Perspective Recognition and Caring, Historical Cultural Positioning (HCP), and Discernment of Presentism (DP) - to be incorporated in film-based history lessons that will help teachers to set purposeful educational goals (MetZGer 2007: 68-72, MARCus et. al. 2010: 9) and empower students "to understand and critically evaluate a movie's intention as an account of the past and its message about how the past relates to the present" (MARCUS et. al. 2010: 8).

\footnotetext{
${ }^{15}$ Definition of media literacy approved by the European Council: "Media literacy is the ability to access the media, to understand and to critically evaluate different aspects of the media and media contents and to create communications in a variety of contexts. ... The aim of media literacy is to increase people's awareness of the many forms of media messages encountered in their everyday lives. Media messages are the programmes, films, images, texts, sounds and websites that are carried by different forms of communication. Media literacy is a matter of inclusion and citizenship in today's information society. It is a fundamental skill not only for young people but also for adults and elderly people, parents, teachers and media professionals. Media literacy is today regarded as one of the key pre-requisites for an active and full citizenship in order to prevent and diminish risks of exclusion from community life." (DING 2011: 5)
}

Pandaemonium, São Paulo, v. 25, n. 45, jan.-abr. 2022, p. 29-65 
SCHAAR, T.; WEN, C.S. - Developing Historical Competency

In order to adequately prepare the students of cohorts $13 \& 14$ for the later conducted film projects by introducing the 5 HLC and to demonstrate the main advantages of working with history films in general, the 2011 movie "Der Ganz Große Traum" ("Traum") directed by Sebastian Grobler was selected for its entertainment value, the content knowledge, the narrative and the dramatized and distorted depiction of the protagonist. The movie supports learning about the political situation, the economic progress and development (industrial revolution) and social conflicts in the $2^{\text {nd }}$ German Reich (1871-1918) which was ruled by the Hohenzollern emperors (and for a certain period shaped by chancellor Bismarck's politics). ${ }^{16}$

Synopsis: Loosely based on a true story, the commercially successful film tells of the young teacher Konrad Koch (played by Daniel Brühl), who in 1874 begins his service at a renowned school, the Martino-Katharineum in Braunschweig, where he is supposed to teach the newly introduced subject "English". At first, English does not meet with much enthusiasm among the students of mostly upper and middle-class background. So, the idealistic Koch resorts to an unusual trick to arouse their interest: he introduces them to a completely unknown and strange sport, which he has encountered during his stay in England - football. Koch wins the students over with his unorthodox method. While the students enthusiastically play the game and embrace the concepts of team spirit, inclusion of former "outsiders" and fair-play, Koch's conservative colleagues as well as influential parents and dignitaries are afraid of any change and want to get rid of the "troublemaker" who threatens the traditional order. When Koch is finally dismissed for insubordination and insolence, his students stand up for him. A public football match convinces the Imperial delegation from Berlin, and the game is introduced in the school curriculum. Football came to Germany. (Der Ganz Große Traum, 2011, DVD)

Content Knowledge is essential for understanding, examining and interpreting

HFs and their purposes and messages (explicit and implied). Students learn critical analytical skills to use HFs as a primary and/or secondary source for historical information, to evaluate the accuracy of the depicted past and to distinguish between fact and fiction.

(METZGER 2007: 69-70, MARCUS et. al. 2010: 8) Through guiding questions which should always accompany the film-viewing and the post-viewing discussion, the BA German students were able to extract (and later compare) historical facts about:

The $2^{\text {nd }}$ German Empire being a class-structured society and ruled by the highly revered Emperor Wilhelm I. / the industrial revolution esp. in communications technology (telegraphs) and the emergence of the working class and its political representatives, the Social Democratic Party / the luxurious living conditions of the upper and middle-class (mansions, villas) in contrast to dreadful living and working conditions of the proletarians (slums, dangerous work, long hours, no rights, minimum wages, child labour) / the role of the Prussian military and the battles of the past e.g. Battle of Sedan 1870 against France / the school system with its focus on teaching values such as patriotism, loyalty to Kaiser and fatherland, honour, discipline, respect, obedience and duty, and on subjects such as history and sports / bodily punishment and incarceration in school for violating rules /

\footnotetext{
${ }^{16}$ It ended with the defeat in World War I and the abdication of Emperor Wilhelm II.
} 
SCHAAR, T.; WEN, C.S. - Developing Historical Competency

attempts to reform the school system by introducing new subjects and supporting gifted underprivileged children / migration to the United States as an alternative for workingclass people / Great Britain as the enemy / women's demand of the right to vote ...

By introducing short biographies of Konrad Koch and Friedrich Hermann and the (translated) text "Fußballanfänge in Deutschland" (GöDECKE 2011), the students were asked to identify and to write down the major discrepancies between historical facts and presentation in film. Students noticed the portrayal of the strict disciplinarian and Ancient Greek, Latin, history and geography teacher Koch as a reform pedagogue, as an English teacher and as a lone rebel against the "old-fashioned rules" of the school and the conservative attitudes of his fellow teachers, which he fought to overcome as well as for the exclusion of important characters in introducing football. No credit was given to Friedrich Hermann $\left(14^{\text {th }}\right.$ September $1835-20^{\text {th }}$ February 1906), the physical education instructor at the Martino-Katharineum - revered in Braunschweig as the "Father of Physical Education" - who actually visited public schools in England and returned with a soccer ball. In "Traum", Hermann is portrayed as Dr. Jessen, one of the staunchest opponents of Koch's introduction of football, preferring gymnastics as a dignified and elegant sports as well as military exercises. Hermann, however, along with Konrad Koch, introduced the game of football to Germany and held the first match in 1874. Herrmann, Koch and military doctor Friedrich Reck - supported by director Karl Gustav Gravenhorst - overcame all prejudices against the game - an English disease, un-manly, un-German, foot crippling, dangerous, one could get dirt on the clothes - and introduced it 1879 into the school curriculum. ${ }^{17}$

In order to critically analyse a narrative, the following guiding questions should be asked: "Why is this film depicting the past in this particular way, from the perspective of these particular characters, and using these particular images, stories, or themes? How do these images, stories, and themes shape the way the past is presented and received by the viewer?" (METZGER 2007: 70) By applying these questions to the movie, the students noticed the constructed nature of the historical interpretations - a key component of historical thinking (MARCUS et. al. 2010: 7) - and realized that certain aspects of historical records needed to be fictionalized, trivialized, embellished or even distorted for dramatic

\footnotetext{
${ }^{17}$ Herrmann later introduced cricket and basketball in Germany. In 1875, Konrad Koch published the first version of the rules of football in German. His version of the game still closely resembled rugby football. (15 against 15, the ball was shaped like a rugby ball, a "Emperor" watched the following of the rules, players could use their hands to play the ball). Koch tried to Germanize the English football rules. (BINZ 2011)
} 
SCHAAR, T.; WEN, C.S. - Developing Historical Competency

and entertainment purposes. It did not diminish the BA students' enthusiasm for the film. The BA students were also made aware that the 2011 (historically rather inaccurate but very charming) version of how football was introduced in Germany by a reform-minded English teacher will probably become the dominant narrative in the future. It will be regarded as a historical document how German filmmakers in the first decade of the $21^{\text {st }}$ century remembered and constructed the story (HCP). Metzger pointed out, that HFs

are made by people at a unique place in time, located within a specific culture with specific collective meanings ... [...] while history movies start out as texts about the past, over time, they themselves become documents of the past, which can be used like primary sources (if not quite as transparent records) from previous eras. (2007: 70)

The film-viewing technique of "shadowing" a particular character ${ }^{18}$ to understand the cultural, political, religious, economic, and social forces of "their world" which determine their actions, motives and decisions was applied in order to develop the HLC Historical Empathy (HE) in its two modes Perspective Recognition (PR) and Empathy as Caring (EC) (BARTON; LEVSTIK 2004: 208; 218-219). PR “involves rational examination of past perspectives, explaining historical actions in terms of the attitudes, beliefs, and intentions of the people of the past" while EC "involves making personal connections to history through topics we want to learn, through moral judgments, and through a desire to help by applying what we learn from history to our world today" (METZGER 2007: 71). While outlining the debate about the concept of empathy and separating it from sympathy, Barton and Levstik (2004: 208) clarified:

Empathy involves using the perspectives of people in the past to explain their actions. To understand why people acted as they did, we need to focus on what they were trying to accomplish, the nature of their beliefs, attitudes, and knowledge, and the culturally and historically situated assumptions that guided their thought and action. ... According to current interpretations, empathy does not involve identification (we want students to understand Hitler's outlook but not accept it as their own), does not depend on imagining oneself in the place of others (because we can never directly relive their experiences or perceptions), and does not involve emotional response (rational understanding is the goal, not sympathy or admiration).

As the vast majority of characters in the movie represent larger groups of people with similar perspectives (compilation characters) and often display (stereo)typical human behaviour and characteristics (independent of time and cultural imprint), their

\footnotetext{
${ }^{18}$ Konrad Koch, the protagonist, Richard Hartung, businessman, politician, chairman of the schoolboard, the antagonist, Director Mersfeld, educational reformer, Dr. Robert Bosch, conservative history teacher, Felix Hartung, the class-leader, Otto Schricker, an non-athletic student with a sense for business, Joost Bornstedt, the "proletarius", target of physical and mental abuse by teachers and students, but (later) the best football player, Clara Bornstedt, single mother and factory worker, who wants her son to become an engineer and migrate to the USA, Rosalie, maid in the Hartung household, who is dismissed for showing affection for Felix.
} 
SCHAAR, T.; WEN, C.S. - Developing Historical Competency

decisions, motives and actions were sufficiently understood and were related to personal experiences of several BA German students such as bullying "misfits" in school, a schoolsystem which discourages critical thinking and expressing one's opinions, marginalizing certain groups in society (e.g. indigenous people in Malaysia such as the Orang Asli), generation-conflicts, having to fulfil parents' ambitions for their children, "forbidden" love, the role of sports in team-building. The movie portrays documented (Robert Koch) and fictional characters (Rosalie, Joost Bornstedt) who by displaying rather modern attitudes, behaviour and even untimely knowledge (Rosalie explains the off-side rule, which did not exist at the time and dreams of football tournaments played by women) form a bridge between the depicted past and the present. Film-based historical instruction must teach students that history films are contemporary art products and filmmakers "often use a historic event as a metaphor for current concerns, attitudes, and values that are easier to sell to contemporary audiences" (METZGER 2007: 71). This can become a problem when presentism distorts characters' motivations and actions and does not contribute to the understanding of the past. The teacher needs to provide enough content support and guiding to discern presentism (DP) (METZGER 2007: 72). Finally, students need to be aware that financial decisions regarding the production and distribution of a film might influence the historical accuracy represented (BYERS 2010).

\section{Historical Feature Film Project (cohort 14)}

In order to explore and to develop the students' HLC (among other pedagogical goals), the authors carried out an extensive history film project (HF-project) titled "Exploring World War II" with BA German cohort 14. It was completed within one academic semester. The project can be regarded as a descriptive case study which used the theory of the important HLC as part of media literacy (ML) as framework. The HF-project applied descriptive case study design strategies and focused on a single unit as homogenous sample: a group of 21 BA German students (17 females, 4 males) in a course setting, which was investigated and evaluated deeply and detailed to meet the objectives and characteristics of a case study. All students were raised in the multi-ethnic and multi-lingual environment of Malaysia; their ages ranged between 20-23 years at the time of the observation; they all shared the same limited knowledge of German history as well as the same levels of German and English language proficiency. The data were collected by applying 
SCHAAR, T.; WEN, C.S. - Developing Historical Competency

qualitative research methods (written group reports and individual assignments based on guiding questions) and were analysed via inductive approach. Students' real names were coded to keep the students' identity confidential. The project was based on the practical teaching examples in US American schools described by Marcus et. al. (2010) ${ }^{19}$. At the same time, it took into account a) earlier experiences of the corresponding author's use of individual history films in BBD3101 (cohort 12) and b) findings and insights the authors had gained from a HF-project with BA German cohort 13 (called the pilot study) ${ }^{20}$ including the critical evaluation of the project by the participants. The results of the pilot study (which focused on exploring all 5 HLC as theoretical framework) allowed the conclusion that due to the lack of historical (and general) knowledge about Germany's current political and social issues, HCP and DP proved to be the competencies which were most difficult and time-consuming to develop (since a great amount of input from the lecturer was required to identify issues and the presentation of it in film for instance). HCP and DP were therefore regarded as less effective in developing HL as part of ML and were mostly neglected in the HF-project of cohort 14 . The theoretical framework was thus adjusted to the theory of three important HLC: CK, NA and HE/PR. Seven selected history films (out of 28 pre-selected HFs) of mostly German and European origin were used as tools to explore and develop the three HLC.

Adjusting the lessons' structures described by Marcus et. al. (2010) the HF-project comprised nine stages: (1) HFs preparation (before the semester started) / (2) creation of groups, distribution of group assignments and pre-selected HFs (week 1) / (3) film selection by groups, preparation of guiding questions (starting week 2) / (4 \& 5) distribution of guiding questions prepared by the groups and screening session (weeks 9-14) / (6) the students answer the guiding questions as individual assignments / (7) collection of all group \& individual assignments (7 days after each screening session) / (8) after-viewing in depth discussions / (9) analysis of data (ongoing). In the first stage of the project, the lecturer searched for history films with English subtitles, since the students' level of German language proficiency was insufficient to watch a HF in German. The majority of the available HFs were related to events of the $20^{\text {th }}$ century such as World War I, World

\footnotetext{
${ }^{19}$ A five-stage class project model was applied by several teachers which focused on using a single history film to develop HLC (MARCUS et. al. 2010: 160).

${ }^{20}$ Each group of 4-6 members was assigned a pre-selection of $10 \mathrm{HF}$ to choose the most suitable film for viewing in class, which proved to be overwhelming and yielded questionable (and biased) selection criteria based on the preference and opinion of a single participant per 2 films. The number of pre-selected films were therefore reduced to 4 per group.
} 
SCHAAR, T.; WEN, C.S. - Developing Historical Competency

War II, Divided Germany and the Cold War, the Berlin Wall, the Reunification of Germany. Since a preliminary survey into preferences of historical periods suggested a greater interest of the BA German students in Nazi Germany, the lecturer decided to focus on World War II in Europe for this class project. The content the lecturer taught in BBD3101 before implementing the HF-project suggested solid (basic) knowledge of the participants with regard to Adolf Hitler/Nazi Germany/World War II/The Holocaust $(1933-1945)^{21}$.

Marcus et. al. stressed that “...films by themselves are not lessons - teachers create lessons, and films are just one possible resource" (2011: 20). Therefore, "reflective planning" is required to find the most suitable history films which fulfil several criteria. The HFs must be in line with the learning outcomes and the educational goals of the project and represent the chosen topics (see below). The HFs need to be of high quality (inclusive an entertaining and memorable narrative) and offer accurate and valid historical content which (transformed into guiding questions) could steer the students towards CK, NA and HE/PR. The HFs "must engage, directly or obliquely, the issues, data, and arguments of the ongoing discourse of history" (ROSENSTONE 1995: 18). HFs which contain excessive, objectionable violence and sexual content (the latter was a major concern considering the female Muslim majority of the group) had to be avoided. (KING 2002) Other sources - lecturer's background information, historical documents, documentaries e.g. needed to relate to the HFs to ensure that the HF-project was regarded by the students as a serious learning experience (see also MARCUS et. al. 2010: 22; 24). Vetrie pleads to choose films "that engage students in creating an environment to think and a desire to communicate" (2004: 41). Seven groups with three members each were formed in stage 2, and each group was assigned a specific theme: Group 1 - The Germans at War; Group 2 - The Holocaust (Death Camps); Group 3 - The Holocaust (Ghettos); Group 4 - Europe under the Swastika (Military Resistance); Group 5 - Europe under the Swastika (Civilian

\footnotetext{
${ }^{21}$ Teaching Content - Hitler's Third Reich and World War II:

A) Hitler's Third Reich: Adolf Hitler establishes a dictatorship 1933/34 / NSDAP and Volksgemeinschaft / Racial policies / The SS and Police System / Economy and Labour 1933-1939 / Foreign Affairs and the Preparation for War (1933-1939); B) World War II - Part I (The War 1939-1944): The "Blitzkrieg" / War of Annihilation - Operation Barbarossa - Invasion of the Soviet Union (1941/42) / Defeat in the East 1943-1944; World War II - Part II (Homefront / Resistance / The Holocaust): Wollt ihr den totalen Krieg? - The War Economy / Organized Resistance (1933-1945) / The Holocaust; World War II Part III - The End of Nazi Germany (June 1944-May 1945): The Final Battles of Nazi Germany - 1944/45.

Several documentaries were included: Apocalypse Hitler (2 Parts, the rise of Hitler and the NSDAP), Apocalypse World War II (Part II, III, V, VI, the most important developments and battles in WWII), The Nazis. A Warning from History, BBC (Part IV, The Road to Treblinka, Holocaust), (Part VI, 1944/1945, the defeat of Nazi Germany)
}

Pandaemonium, São Paulo, v. 25, n. 45, jan.-abr. 2022, p. 29-65 
Resistance); Group 6 - 1945 (The last Days of Nazi Germany); and Group 7 - 1945 (Between War and Peace). Each group also received four pre-selected history films (28 HF) which represented creativity and diversity of $20^{\text {th }} / 21^{\text {st }}$ century German and world cinema and the instructions below (which were outlined in detail) for project stage 3 . The groups were comprehensively briefed about the theory and characteristics of the important historical literacy competencies and were asked to create viewing questions based on this theory. Each group was given seven weeks' time to complete their task. They were encouraged to consult the lecturer if they encountered any difficulties in writing the report or while creating guiding questions.

\section{Historical Feature Film Project BBD 3101 Dear students,}

1. Please make sure that you watch every film assigned to your group; either all group-members watch all the films, or you distribute the films among the group-members and trust their judgments. In order to make a good choice, we suggest the first option.

2. Choose the film, which "best" represents the time period or the event. Do not choose the film based on emotional criteria such as: the movie is boring, the movie is too violent, it contains nudity...

3. Although prior lectures will be provided, you are encouraged to familiarize yourselves further with the historical backgrounds (textbooks, documentaries, articles) of the events.

4. Consult websites such as rottentomatoes.com, Metacritic.com, imdb.com for popular and professional opinions on the films. Keep the criticism in mind before deciding, but also take your classmates viewing habits and preferences into account.

5. Protocol your selection process step-by-step. Your written report shall include the following:

(1) Selection of criteria and all the pros and cons which arise in your debates and arguments;

(2) Group discussion details - frequency of having a group discussions, dates and times, durations, who says

what (significant points of view), debates among members on points of view, arguments;

(3) Name the Top 3 films and explain your decision;

(4) Write a short synopsis and summarize the general comments (positive and negative!) from professional

critics for the Top 3 films;

(5) Provide reasons of why the other films are not being listed in your Top 3;

6. Organize the film viewing (time, room, technical check etc.)

7. Explain your choice of film to your classmates before the movie screening (A pre-viewing presentation)

8. Prepare viewing-questions for your classmates (Please show the questions to us at least 2 days before the viewing event).

Hopefully, this project will get you further interested in German history, and in history films. It aims to improve your historical literacy competencies and your decision-making skills; to encourage teamwork and to contribute to the development of critical thinking. I wish all of us a lot of fun and great success. Please do not hesitate to contact us for all matters related. Use the FB-group as a medium for discussion and exchange of thoughts.

Involving the BA students in the final selection process not only encourages autonomous learning and a collective learning experience (see e.g. FAISTAUER 2010, BROWN 2011); it created a shared perspective on how to analyse a movie and offered a great sense of responsibility for choosing the "right" movie for the screening based on 
SCHAAR, T.; WEN, C.S. - Developing Historical Competency

their acquired knowledge of the given topic, their cinematic competencies and their ability to learn from each other, assist each other and work as a team ${ }^{22}$. All group reports showed that the members met four to six times to discuss the films, which were usually distributed among and watched by individual group members to establish the selection criteria and to make the final choice of the film to be shown. The authors would have liked all group members to watch all four films to unify the selection process. However, this was not possible due to time constraints and the heavy workload during the semester. As a result, decisions for or against a film were often based on personal preferences, biases or problems of understanding the content or the narrative. Although, it was impossible to make a completely "wrong choice", it must be concluded that this stage needs more guidance by the lecturer.

The following overview shows a) the theme of each group, b) the pre-selected films, c) the film, which was finally selected for screening (selection by the students, preference by the lecturer) and d) the goal-oriented selection criteria:

\section{Group I - Germans at War / The „Home Front“"}

Films

1. Die Weiße Rose / The White Rose (West Germany, 1982),

Director: Michael Verhoeven

Students' selection Lecturer's choice

2. Sophie Scholl - The Last Days (Germany, 2005),

Selected Film

3

Director: Marc Rothemund

The movie shows the last days in the life of 21-year-old Sophie Scholl, a member of the non-violent student resistance group "White Rose”. For distributing anti-Nazi leaflets, the People's Court found Sophie Scholl guilty of high treason. She, her brother Hans and other resistance fighters were executed on $22^{\text {nd }}$ February 1943.

3. Edelweiss-Piraten / Edelweiss Pirates (Germany, 2004),

2

4

Director: Niko von Glasow

4. Napola (Germany, 2004), Director: Dennis Gansel

4

1

Selection criteria: a) the depiction of the political situation in Nazi-Germany b) the depiction of the "normality" of life under the conditions of war c) conformity or acts of resistance d) human interest stories and the emotional impact $\mathrm{e}$ ) the film as source of historical information $\mathrm{f}$ ) mise en scène

\section{Group II/1 - The Holocaust (Death Camps)}

Films Students' selection Lecturer's choice

1. Colette / Prisoners of Auschwitz (Czech Republic, Slovakia, 2013), 4 1 Director: Milan Cieslar

\footnotetext{
22 The teams were randomly chosen, and were not based on friendships, the same ethnic background or students being roommates in the dormitory. As intended, it brought together students in a group that normally did not work together, since in Malaysian classrooms, it is common that students of the same ethnic origin stay among themselves. It also meant that a certain amount of logistics was needed to coordinate the different lesson plans (due to the different minor subjects the students pursued) for meetings. While one group member was "elected" as "leader", another was responsible for taking the minutes of the meetings. These were later made available in the group reports.
}

Pandaemonium, São Paulo, v. 25, n. 45, jan.-abr. 2022, p. 29-65 
SCHAAR, T.; WEN, C.S. - Developing Historical Competency

2. Saul Fila / Son of Saul (Hungary, 2015), Director: László Nemes

3. The Grey Zone (Spain, 2001), Director: Tim Blake Nelson

Selected Film

2

The movie is based on the book "Auschwitz: A Doctor's Eyewitness Account" by Dr. Miklós Nyiszli, assistant to the notorious Josef Mengele, medical doctor in Auschwitz. It depicts the story of the "Sonderkommando XII" and the uprising in October 1944. These Jewish prisoners are made to assist the SS-guards in shepherding the Jewish victims into the gas chambers and the disposing of the bodies in the crematorium.

4. Sorstalanság / Fateless (Hungary, 2005), Director: Lajos Koltai 2 4

Selection criteria: a) the depiction of Holocaust-events - authentic feeling, focus on concentration / death camps b) the depiction of the persecution and suffering of the Jews c) human and inhuman behavior of characters d) human interest stories and the emotional impact e) the film as source of historical information f) mise en scène

\section{Group II/2 - The Holocaust (The Ghetto Experience)}

Films

1. The Pianist (France, Germany, Poland, UK, 2002),

Students' selection

Lecturer's choice

Director: Roman Polanski

The biographical drama, directed by Holocaust survivor Roman Polanski, tells the incredible survivalagainst-all-odds story of the Polish Jewish pianist and composer Wtadystaw Szpilman in the Warsaw ghetto and in the ruins of the Polish capital after the liquidation of the ghetto. The multi-award-winning movie is an adaptation of the autobiography "The Pianist: The Extraordinary True Story of One Man's Survival in Warsaw, 1939-1945".

2. The Courageous Heart of Irena Sendler (Poland, USA, 2009), Director: John Kent Harrison

3. Jakob der Lügner / Jakob the Liar (East Germany, 1975), Director: Frank Beyer

4. Ghetto (Germany, Lithuania, 2006), Director: Audrius Juzenas

2

3

4
3

2

4

Selection criteria: a) the depiction of Holocaust-events - authentic feeling, focus on the Jewish ghettos b) the depiction of the persecution and suffering of the Jews c) human and inhuman behavior of characters d) human interest stories and the emotional impact e) the film as source of historical information f) mise en scène

\section{Group III/1 - Europe under the Swastika (Military Resistance)}

Films Students' selection Lecturer's choice

1. Miasto 44 / City 44 (Poland, 2014), Director: Jan Komasa 2 3

2. Brestskaya Krepost / Brest Fortress (Belarus, Russia, 2010), Director: Aleksander Kott

3. Dark Blue World (Czech Republic, UK, 2001), Director: Jan Svěrák 4

4. Stalingrad (Russia, 2013), Director: Fedor Bondarchuk

Selected Film

2

Bookended by the Fukushima catastrophe, the action-packed movie is set in November 1942 during the Battle of Stalingrad. The elderly Russian narrator (calming down trapped young Germans in the ruins of Fukushima) tells the story of his "five fathers" in Stalingrad, a ragtag group of soldiers who defended a residential building in the already badly damaged town against continuing attacks by the German troops. The five soldiers - each representing the unspeakable suffering of the Soviet people in World War II encountered a young woman in the building whose family was killed in an air-raids. Katya became a symbol for each of them-Mother Russia, a sister, a wife, a lover -, which they tried to protect against all odds. At the end, the building was leveled by an air-strike, only Katya survived.

Selection criteria: a) the depiction of battles - authentic feeling, scale b) the depiction of the suffering of civilians and soldiers c) human and inhuman behavior of characters d) human interest stories and the emotional impact e) the film as source of historical information $\mathrm{f}$ ) mise en scène

Pandaemonium, São Paulo, v. 25, n. 45, jan.-abr. 2022, p. 29-65 
SCHAAR, T.; WEN, C.S. - Developing Historical Competency

\section{Group III/2 - Europe under the Swastika (Civilian Resistance)}

Films

Students' selection

Lecturer's choice

1. Süskind (Netherlands, 2012), Director: Rudolf van den Berg

Selected Film 1

Hero or traitor? The Holocaust-themed film is set in Amsterdam during the Second World War. It depicts the secret attempts of Walter Süskind, a German Jewish businessman and member of the Jewish Council, and a group of Dutch people to help Dutch Jewish children escape deportation and death in Nazi extermination camps. Branded by his fellow Jews as Nazi-collaborator due to his seemingly friendly relationship with the SS-officer in charge of deportation, the Süskind group saved more than 600 children from certain death. Süskind and his family, however, were killed at Auschwitz.

2. Joanna (Poland, 2010), Director: Feliks Falk

4

3

Flame \& Citron (Denmark, Germ
Director: Ole Christian Madsen

4. Perlasca - Un eroe Italiano / Perlasca - An Italian Hero (Italy, 2002), Director: Alberto Negrin

Selection criteria: a) the depiction of acts of civilian resistance b) the depiction of the German occupation regime c) human and inhuman behavior of characters d) human interest stories and the emotional impact e) the film as source of historical information $\mathrm{f}$ ) mise en scène

\section{Group IV/1 - 1945 (The Last Days of Nazi Germany)}

Films

1. Dresden (Germany, 2006), Director: Roland Suso Richter

Students' selection Lecturer's choice

2. Der Untergang / Downfall (Germany, Italy, Austria),

Director: Oliver Hirschbiegel

The high grossing and Academy Awards nominated movie thematises in detail the last days of Adolf Hitler and other NSDAP-, Wehrmacht- and SS-leaders (such as Goebbels, Himmler, Bormann, Speer, Keitel, Jodl) in the Führerbunker underneath the Reich Chancellery in April 1945 and the downfall of Berlin and Nazi-Germany. Bookended by commentaries given by Hitler's private secretary Traudel Junge and based on memoirs, eye-witness accounts and historical sources the movie sparked a critical debate about the depiction of Hitler "as a human being" side as well as the positive portrayals of the SS-officers ErnstGünther Schenck and Wilhelm Mohnke.

3. Vier Tage im Mai / Four Days in May (Germany, Russia, Ukraine, 2011), 3 Director: Achim von Borries

4. Ich war Neunzehn / I was Nineteen (East Germany), Director: Konrad Wolf

Selection criteria: a) the survival and death of civilians and soldiers in $1945 \mathrm{~b}$ ) depiction of extraordinary events such as bombing raids, mass rape c) the role of the NSDAP in the final weeks of Nazi Germany d) Adolf Hitler and leading Nazi leaders e) the military defeat of Germany f) the persecution of Jews / the Holocaust $g$ ) human and inhuman behavior of characters $h$ ) human interest stories and the emotional impact i) the film as a source of historical information $\mathrm{j}$ ) mise en scène

\section{Group IV/2 - 1945 (Between War and Peace)}

Films Students' selection Lecturer's choice

1. Lore (Germany, Australia, 2013), Director: Cate Shortland

Selected Film

1

The award-winning international co-production is based on Rachel Seiffert's novel , The Dark Room “. 15 year-old Lore is the daughter of a high-ranking SS-officer, a wanted war-criminal, who was involved in the Euthanasia programme and in the Holocaust. When her parents disappear, Lore takes her four younger siblings on an ordeal through defeated, divided and occupied Germany to her grandmother in Northern Germany. Accompanied by the mysterious Thomas, who pretends to be a Jewish concentration camp survivor, Lore encounters perpetrators and victims along the way, and she soon faces the truth about everything she believes in - in Adolf Hitler, the glory of the Vaterland, the superiority of the Aryan race, in her parents. And in order reach her destination safely, she needs to trust a person who she was taught to hate.

2. Róza / Rose (Poland, 2011), Director: Wojciech Smarzowski

4

4

Pandaemonium, São Paulo, v. 25, n. 45, jan.-abr. 2022, p. 29-65 
3. Anonyma - Eine Frau in Berlin / Anonyma - A Woman in Berlin

(Germany, Poland, 2008), Director: Max Färberböck

4. Germania anno zero / Germany Year Zero (Italy, 1948), Director: Roberto Rossellini
2

3

3

Selection criteria: a) the depiction of the political and economic situation in defeated Germany b) the suffering of German civilians esp. women and children, mass rape, hunger, flight, homelessness c) the role of the Allied victors and acts of revenge d) the aftermath of the Holocaust e) the fate of Nazi war-criminals and their families $\mathrm{h}$ ) human interest stories and the emotional impact $\mathrm{i}$ ) the film as a source of historical information $\mathrm{j}$ ) mise en sèene

Due to the enormous importance of creating about ten guiding questions as part of the group assignments which explored and developed the selected three HLC (without completely neglecting DP and HCP), but also taking the difficulties of formulating HLCfocused questions into account, the lecturer reviewed (and in several cases changed) the film-viewing-guiding-questions provided by the groups two days in advance of the screening. The approximately 700 guiding questions and/or tasks to ensure attentive film viewings and which served as the individual assignments can be categorized as follows:

Table 3 - Categories of tasks and questions

\begin{tabular}{|c|c|c|}
\hline Questions and Tasks & Instructions / selected examples & HLC \\
\hline $\begin{array}{l}\text { related to facts / situations / events } \\
\text { / organisations }\end{array}$ & describe, name, explain ... & $\mathrm{CK}$ \\
\hline $\begin{array}{l}\text { related to characters / their relation- } \\
\text { ships / their motives / their strug- } \\
\text { gles }\end{array}$ & describe, analyse, explain, assess, interpret & $\begin{array}{l}\mathrm{CK}, \mathrm{NA}, \\
\mathrm{HE}\end{array}$ \\
\hline $\begin{array}{l}\text { to "shadow" one character for in- } \\
\text { depth analysis }\end{array}$ & $\begin{array}{l}\text { Konrad Koch - Der Ganz Große Traum / Sophie } \\
\text { Scholl, Interrogator Robert Mohr - Sophie Scholl. } \\
\text { Die letzten Tage / Walter Süskind, SS-Hauptsturm- } \\
\text { führer Ferdinand aus der Fünten - Süskind / SS-Ober- } \\
\text { scharführer Erich Mußfeldt, the Jewish doctor Miklós } \\
\text { Nyiszli - The Grey Zone ... }\end{array}$ & $\mathrm{HE} / \mathrm{PR}$ \\
\hline $\begin{array}{l}\text { to express personal opinions about } \\
\text { the depiction of events, characters, } \\
\text { situations }\end{array}$ & $\begin{array}{l}\text { The depiction of Adolf Hitler and other leading Nazis } \\
\text { (Albert Speer, Joseph Goebbels) in Der Untergang }\end{array}$ & NA \\
\hline $\begin{array}{l}\text { to distinguish between facts and } \\
\text { fiction / documented and fictional } \\
\text { characters }\end{array}$ & $\begin{array}{l}\text { discuss the use of fictional storylines / fictional char- } \\
\text { acters from a film-maker's point of view / to what ex- } \\
\text { tent were the characters based on historical evidence } \\
\text { and to what extent were they fictionalised? }\end{array}$ & $\mathrm{CK}, \mathrm{NA}$ \\
\hline $\begin{array}{l}\text { to interview a documented or fic- } \\
\text { tional character }\end{array}$ & $\begin{array}{l}\text { Why did you choose the character? Which questions } \\
\text { would you ask him / her? }\end{array}$ & $\mathrm{HE}$ \\
\hline $\begin{array}{l}\text { about film as a source for historical } \\
\text { information including: } \\
\text { about an overall understanding of } \\
\text { the event / situation / person(s) / or- } \\
\text { ganisations and questions which re- } \\
\text { mained unanswered }\end{array}$ & $\begin{array}{l}\text { Der Ganz Große Traum: education system, class- } \\
\text { system, role of the Prussian military, England and } \\
\text { France as enemies, the industrial revolution, the Kai- } \\
\text { ser; } \\
\text { The Pianist / The Grey Zone / Süskind: the discrim- } \\
\text { ination, persecution and extermination of the Jews in } \\
\text { World War II, the POV of perpetrators (SS officers), } \\
\text { the struggle of Jew helpers; } \\
\text { Der Untergang: the end of World War II from the } \\
\text { perspective of Hitler's inner circle, military com- } \\
\text { manders, Hitler youth members and civilians; } \\
\text { Lore: post-war occupied Germany }\end{array}$ & $\begin{array}{l}\text { CK, NA, } \\
\mathrm{HE}\end{array}$ \\
\hline
\end{tabular}

Pandaemonium, São Paulo, v. 25, n. 45, jan.-abr. 2022, p. 29-65 


\begin{tabular}{|c|c|c|}
\hline $\begin{array}{l}\text { about sequences / scenes, which } \\
\text { could be interpreted as key se- } \\
\text { quences / scenes } \\
\text { about scenes, which had an emo- } \\
\text { tional impact on the viewers }\end{array}$ & $\begin{array}{l}\text { name, describe and explain, discuss, state your rea- } \\
\text { sons, interpret ... } \\
\text { Why does this film present the past in this special } \\
\text { way: from the perspective of these special characters } \\
\text { and why does it use these pictures, stories or themes? } \\
\text { How do these pictures, stories and themes shape the } \\
\text { way the past is presented and the way the viewer is } \\
\text { included? }\end{array}$ & NA, HE \\
\hline $\begin{array}{l}\text { to discuss the issue of "historical } \\
\text { truth" in history films } \\
\text { to discuss the problematic of au- } \\
\text { thenticity in history films }\end{array}$ & $\begin{array}{l}\text { compare depicted events / historical characters with } \\
\text { other sources (texts, documentaries) and notice the } \\
\text { differences / discussion whether fictional characters } \\
\text { or storylines will have an influence on the persuasive- } \\
\text { ness of the film }\end{array}$ & $\mathrm{CK}, \mathrm{NA}$ \\
\hline $\begin{array}{l}\text { pre-viewing speculating about the } \\
\text { title or post-viewing interpretation } \\
\text { of the title }\end{array}$ & $\begin{array}{l}\text { Der Ganz Große Traum } \\
\text { The Grey Zone } \\
\text { Der Untergang }\end{array}$ & NA \\
\hline $\begin{array}{l}\text { about advantages of and re- } \\
\text { strictions in film narratives }\end{array}$ & $\begin{array}{l}\text { ethical questions regarding the depiction of the Holo- } \\
\text { caust, graphic depiction of violence and death, sex } \\
\text { scenes, sexual violence/rape, the scale of battlefield } \\
\text { action }\end{array}$ & NA, HE \\
\hline $\begin{array}{l}\text { to train a multi-perspective point of } \\
\text { view by watching films from dif- } \\
\text { ferent countries about the same } \\
\text { event }\end{array}$ & $\begin{array}{l}\text { e.g. Stalingrad } 1993,(\text { Germany) and } \\
\text { Stalingrad 2013, (Russia) }\end{array}$ & $\begin{array}{l}\text { NA, HE, } \\
\text { CK, } \\
\mathrm{HCP}\end{array}$ \\
\hline to analyse critical reviews of a film & $\begin{array}{l}\text { the perception of a film by experts and viewers and its } \\
\text { positioning in the "zeitgeist" }\end{array}$ & $\mathrm{HCP}$ \\
\hline about film as a teaching tool & $\begin{array}{l}\text { pros and cons-arguments whether the film is suitable } \\
\text { to be shown in L2/L3 German class }\end{array}$ & \\
\hline $\begin{array}{l}\text { about scenes, which could / should } \\
\text { be included in German as Foreign } \\
\text { Languages lessons }\end{array}$ & $\begin{array}{l}\text { Which scenes are suitable to illustrate certain events } \\
\text { e.g. the Battle of Stalingrad / the Holocaust }\end{array}$ & $\begin{array}{l}\mathrm{CK}, \mathrm{NA}, \\
\mathrm{HCP}\end{array}$ \\
\hline $\begin{array}{l}\text { about previous film viewing expe- } \\
\text { riences }\end{array}$ & Compare, discuss ... & \\
\hline $\begin{array}{l}\text { to train critical thinking by analys- } \\
\text { ing controversial decisions made } \\
\text { by characters or groups of charac- } \\
\text { ters, by debating thought-provok- } \\
\text { ing quotes etc. }\end{array}$ & $\begin{array}{l}\text { the role of the Jewish Councils and the Jewish Police } \\
\text { in the ghettos - The Pianist, Schindler's List / Walter } \\
\text { Süskind's decision to collaborate with and to befriend } \\
\text { a SS-officer to carry out his rescue mission of Dutch } \\
\text { Jewish children - Süskind / the role of the Jewish vol- } \\
\text { unteers for the Sonderkommando in Auschwitz as part } \\
\text { of the killing machine - The Grey Zone }\end{array}$ & $\mathrm{HE} / \mathrm{PR}$ \\
\hline $\begin{array}{l}\text { to relate content to current political } \\
\text { / social issues }\end{array}$ & $\begin{array}{l}\text { Racism / discrimination of minorities / religiously } \\
\text { motivated conflicts/ the Israel-Palestine-Conflict with } \\
\text { regard to the Holocaust / German-Russian-relation- } \\
\text { ships / rape as a weapon in military conflicts / the role } \\
\text { of sports for social relations / the manipulation of the } \\
\text { youth in totalitarian regimes or for political agendas }\end{array}$ & $\mathrm{DP}, \mathrm{HE}$ \\
\hline about technical aspects of films & $\begin{array}{l}\text { camera perspectives in Lore, Son of Saul / set design } \\
\text { in The Pianist, The Grey Zone, Der Untergang) / } \\
\text { sound editing in The Grey Zone, the sound of the air- } \\
\text { ing out of the gas chamber / Holocaust iconography - } \\
\text { trains, smoking chimneys, empty spaces, piles of ash, } \\
\text { piles of clothes, suitcases ... The Pianist, The Grey } \\
\text { Zone }\end{array}$ & \\
\hline about discussing "cultural issues" & $\begin{array}{l}\text { is the film suitable for the audience, e.g. young Malay } \\
\text { adults, Muslims / young Chinese Malaysian adults? }\end{array}$ & \\
\hline additional tasks & $\begin{array}{l}\text { write an alternative ending / write a scene from the } \\
\text { Point of View of a certain character / write a film syn- } \\
\text { opsis / write a critical review of a film / viewers as }\end{array}$ & \\
\hline
\end{tabular}


SCHAAR, T.; WEN, C.S. - Developins Historical Competency

\begin{tabular}{|l|l|l|}
\hline & $\begin{array}{l}\text { filmmakers - what would you have done differently? } \\
\text { (debating scenes and endings of films) }\end{array}$ & \\
\hline
\end{tabular}

Source: Prepared by the authors

The seven HFs were then shown during regular classes starting in week 9 (until week 14). Before each film screening, the group members gave a short introduction and an explanation why they had chosen this film without spoiling the content. The guiding questions for the film viewing were handed out and had to be answered by all students including group members who created them (stages $4 \& 5$ ). The students answered the questions at home (based on the films alone and without using the internet) and submitted the results (stages $6 \& 7$ ). ${ }^{23}$ The after-viewing-discussions finally took place after the individual assignments were submitted. This ensured that the written answers were based on the students' own perceptions and HLC and not on the results of the questions' analyses by the lecturer (stage 8). Paper-based document files were created as data sources, and an inductive approach was used for data analysis.

\section{Results (all cohorts)}

How did the BA German students perceive the implementation of history films and history film projects as teaching tools?

At the end of each BBD3101-course, the students of the cohorts 12-15 (a total of 100) were asked to fill in a questionnaire, which consisted of three main areas:

a) the subjective assessment of the watched HFs and documentaries -24 items,

b) learning preferences -17 items,

c) critical thinking and media literacy -29 items,

The average value of the respondents' level of agreement to the survey's statements was calculated from a five-point ordinal Likert scale by choosing $5=\mathrm{I}$ totally agree $/ 4=\mathrm{I}$ quite agree $/ 3=$ undecided $/ 2$ = I slightly disagree $/ 1=$ I totally disagree.

a) Subjective assessment of the HFs

The respondents "quite agreed" (4.11) to the statement "I liked to watch the history films in BBD 3101", even though the statements "I am interested in history" and "In my free time, I like to watch history films or series" scored "undecided" (3.2 and 2.95). The

\footnotetext{
${ }^{23}$ The assignments were marked as part of the final grade for course BBD3101.
} 
SCHAAR, T.; WEN, C.S. - Developing Historical Competency

numbers of HFs shown to each cohort varied according to the different teaching approaches and selected historical periods taught in each of the BBD3101 courses. Since Cohorts $13^{24}$ and 14 included film projects, the students watched 9 HFs. Whereas in the BBD3101 courses that did not include film projects, 5 HFs were screened. The HFs covered specific events in the following historical periods: $16^{\text {th }}$ century, Reformation / The $2^{\text {nd }}$ German Reich, 1871-1918 / World War I, 1914-1918 / World War II and The Holocaust, 1939-1945 / Occupied Germany, 1945-1949 / Divided Germany, German Democratic Republic and Federal Republic of Germany, 1949-1990. The most popular movies - based on selected criteria such as entertainment value, content, narrative, emotional impact and human interest-stories - were "Napola" (2004) - a friendship drama of two teenage boys set at a Nazi elite youth academy, "Der Ganz Große Traum" (2011) and the against-all-odds Holocaust survival story of the Polish musician Władysław Spilmann in the Warsaw ghetto - "The Pianist" (2002). In addition, the controversial depiction of Hitler's last days in "Der Untergang” (2004), the Holocaust dramas “The Grey Zone” (2001) and "Süskind" (2012) as well as the action-packed Berlin-Wall-themed movie "Der Tunnel" (2001) and the comedy "Sonnenallee" (1999) - a literary adaptation about a group of teenagers in East/Berlin of the late $1970 \mathrm{~s}^{25}$ - were given quite high scores. The movie with the lowest score is "Lore", which depicts the previously untold story of children of German war-criminals in the aftermath of World War II. The technical and aesthetic design of the film in terms of the use of many close-ups (faces, feet, hands) and the slow narrative tempo and many symbol-laden scenes that needed further explanation did not correspond to the students' usual film viewing habits and therefore were very demanding and exhausting for them to grasp. Furthermore, the resistance drama "Sophie Scholl. Die letzten Tage" which is based on the transcripts of the authentic interrogation presented through interviews between Sophie Scholl and her interrogator was not eventful enough for the students and therefore achieved a low rating. ${ }^{26}$

\footnotetext{
${ }^{24}$ The pilot study - a HF project which encompassed the time periods from 1933 to 1990 - was conducted in cohort 13. The HF were selected by students; Group I - The War: Stalingrad (Germany, 1993), Director: Joseph Vilsmaier / Group II - The Holocaust: Colette / Prisoners of Auschwitz (Czech Republic, Slovakia, 2013), Dir.: Milan Cieslar / Group III - Young People in World War II: Hitlerjunge Solomon (Germany, Poland, France, 1990), Director: Agnieszka Holland / Group IV - 1945 - The Year of War and Peace: Anonyma - Eine Frau in Berlin / Anonyma - A Woman in Berlin / Group V/1 - Divided Germany - East Germany: Sonnenallee (Germany, 1999), Director: Leander Haußmann/ Group V/2 - Divided Germany West Germany: Das Wunder von Bern / The Miracle of Bern (Germany, 1999), Director: Sönke Wortmann. ${ }^{25}$ Thomas Brussig. Am kürzeren Ende der Sonnenallee. 1999.

${ }^{26}$ The overall (subjective) ranking of the HF out of 5.00: Napola (Germany, 2004) - 4.86 / Der Ganz Große Traum (Germany, 2011) - 4.59 / The Pianist (Poland, Germany, France, 2002) - 4.39 / Der Untergang (Germany, 2004) - 4.35 / Der Tunnel (Germany, 2001) - 4.35 / Sonnenallee (Germany, 1999) - 4.25 / The
} 
SCHAAR, T.; WEN, C.S. - Developing Historical Competency

b) Learning Preferences

In addition to specific characteristics and attitudes towards the target language German, each BA German student has different preferences when it comes to learning (history). Based on their statements, the respondents can be classified as auditory (4.00) and visual learners (4.30); however, the preferred method of teaching history was a mix of textbook excerpts, presentations, documentaries and history films (4.65/I totally agree). The HFprojects also aimed to support communicative learners.

The participants favoured to watch the whole history movie rather than just selected scenes / sequences to enjoy the complete aesthetic experience (4.59/I totally agree). They dismissed the statement "History movies are only entertainment, but not a source of information in class" (1.47/I totally disagree) but were contradictory in their statements whether "History movies can be the main source of information in history class" (3.70/ I quite agree) and "History movies can only be an additional source of information in history class" (3.63/I quite agree). That the students attach great significance to history films is shown by the "I quite agree"-score to "History films can change the existing perception of historical events in a positive or a negative way" and by the "undecided"-score (3.05) to the statement "History movies can never replace textbooks in class". With regard to the film viewing experience itself, the participants "quite agreed" upon their need "to get explanations about the depicted historical events/persons before watching the history movie" (4.09), the importance of "the participation of students in the film selection process for the history class" (3.97), the necessity of having "precise guiding questions for a film viewing in order to focus on events, characters, scenes, dialogues etc." (4.26) as well as "to discuss history movies after the screening in order to understand it better" (4.29). They also stressed the importance "to be educated properly in film/media techniques in order to interpret the film/media message correctly" (4.0) before films are being implemented in class. The search for information about the movie (director, writer, actors, plot, message, etc..) after the film viewing in class was a commonly practiced more by the students (4.01) than before the film viewing (2.57).

Grey Zone (USA, 2001) - 4.20 / Anonyma. Eine Frau in Berlin (Germany, 2008) - 4.18 / Süskind (The Netherlands, 2012) - 4.17 / Luther (Germany, USA, UK, 2003) - 4.17 / Das Wunder von Bern (Germany, 2003) - 4.14 / Hitlerjunge Salomon (Germany, France, Poland, 1990) - 3.96 / Das Wunder von Berlin (Germany, 2008) - 3.95 / Stalingrad (Germany, 1993) - 3.91 / Stalingrad (Russia, 2013) - 3.76 / All Quiet on the Western Front (USA, 1979) - 3.71 / Colette - Prisoners of Auschwitz (Czech Republic, Slovakia, 2013) - 3.60 / Dresden (Germany, 2006) - 3.60 / Sophie Scholl - Die Letzten Tage (Germany, 2005) 3.05 / Lore (Australia, Germany, 2011) - 2.03. The students claimed that they liked to watch the historical documentaries (3.71/I quite agree).

Pandaemonium, São Paulo, v. 25, n. 45, jan.-abr. 2022, p. 29-65 
SCHAAR, T.; WEN, C.S. - Developing Historical Competency

c) Critical thinking \& Media literacy

There was a broad consensus (I totally agree) that history movies "bring the past and people 'to life" (4.56); convey "a 'feeling for the time' through period costumes, everyday items, scenery, furniture, transport means etc." (4.56) and help the students "to understand and therefore remember the events / persons of the past better" (4.67). The students "quite agreed" to the statements: "The dramatized stories and emotions used in history movies stimulate me intellectually" (4.16), "History movies motivate me to study the periods / events / persons further" (4.23), "History movies help me to develop a historical conscience" (4.16) and "In our digital world, people will learn history more through films than through textbooks" (4.23). The data analysis suggests that the majority of the students - despite being aware that a history movie is a contemporary art product and "only an artistic interpretation of the historical truth (a selected truth)" (3.89/I quite agree) - was fixated on "historical truth" being conveyed through film. ${ }^{27}$ For "study purposes" and "test-preparation" they gave preference to documentaries and documentarystyle history dramas over feature films, expressing their beliefs that "Documentaries are more useful as teaching tools than history films" (4.39/I quite agree) and "Documentaries are closer to the historical truth than history films" (4.10/I quite agree). The statement "Documentaries also show only a selected truth" scored an "undecided" (3.35). A number of respondents raised concerns about distorted, biased or wrong historical information in films and a possible misinterpretation of depicted events (3.81/ I quite agree), the misuse of history films for political propaganda (4.39/I quite agree) and that HFs could "teach audiences political, racist, sexist messages (messages against countries, minorities etc.)", (3.93/I quite agree). They "totally agreed" that "A history movie should only convey the truth" (4.67). Several respondents indicated uncertainty about the introduction of fictional characters and storylines in history films and mentioned insecurities in distinguishing between them and "real events and characters" (3.42). BA German students prefer a "clear message" in a history film (4.65/I totally agree) and teacher's guidance and explanations,

\footnotetext{
${ }^{27}$ CF1/C14: (unedited) "Historical truth means what ACTUALLY happened. Not the type of "historical truth" that governments intend to rewrite in order to brainwash the people. For me, I watch documentaries and learn history to know what happened in the past, not some ideology-inspired "facts" to be brainwashed. Historical truth requires authentic facts and no alteration of any form of information. This is what I believe in the ultimate truth, without any biasness in the information being fed to me. Have a perception, what if people from different countries learned their history that is being altered depending on which country they are from, when people from different countries all around the worlds unite and talk about history, all of the historical facts don't match at all. For example, Japan is one of them. Rewriting the facts about the war and the deeds the empire did in the past. That is why I say the unbiases of historical truth is important. Unless they don't exist after all."”
} 
SCHAAR, T.; WEN, C.S. - Developing Historical Competency

since the statement "I am confident that I can analyze a history film without any explanation/teacher's input/textbook" scored just 2.37 (I quite disagree). However, they expressed confidence in their ability to relate history films to important and current issues and values (4.14/ I quite agree). Students are aware that history films have certain disadvantages compared to other historical sources such as documents, texts and even documentaries but also have the power "to change the existing perception of historical events in a positive or negative way" (4.06/I quite agree). Reflecting on the HF-project or the implementation of a few films in class, the BA German students totally agreed that "history films should be an integral part of history classes" (4.57). An interest to "watch history films from different countries on the same historical event in order to experience the different perspectives" was also indicated 4.28/I quite agree).

Which of the selected three historical competencies have been particularly developed through film work or film projects?

\section{A) Content Knowledge}

Each of the seven sets of guiding questions (individual assignments) included tasks or questions to explore and to develop $\mathrm{CK}$ as the basis for understanding the displayed filmic reconstruction and interpretation of selected historical events. Validated facts (and documented persons) which the BA students had already studied during the academic lectures (week 1-8) needed to be recognized and set apart from fictional characters and sub-plots. ${ }^{28}$ For The Pianist (2002), the participants needed to explore the fundamental changes (15 categories) in the life of Polish Jews during the German occupation, as well as to describe their sufferings in the Warsaw ghetto. Based on the analyses of individual assignments, it can be concluded that all participants fulfilled the task. $62 \%$ of historical content was recognized on average per participant $(\mathrm{N}=20)$. 9 out of 15 categories were described by more than $50 \%$ of the participants.

Table 4 - Expected answers as categories of CK - The Pianist

\section{How did the life of Polish Jews change during the German occupation? ( $\mathrm{N}=20)$}

Recognized and described by $\%$

$60 \%$

\footnotetext{
${ }^{28}$ CK related questions: Sophie Scholl - Die letzten Tage: the living conditions of German civilians in early 1943 / The Grey Zone: the situation of the Jewish Sonderkommando in Auschwitz and the process of mass killings of Jews in Auschwitz in 1944 / Süskind: Nazi occupied Holland and the rescue of hundreds of Jewish children by Walter Süskind and a network of resistance fighters / Der Untergang: Hitler and the NSDAP-leadership in the last days of Nazi-Germany, April/May 1945; the situation of civilians in Berlin.
} 
SCHAAR, T.; WEN, C.S. - Developing Historical Competency

passed

e.g. Jews were not allowed in certain places

Jews were labeled with the Star of David $\quad 100 \%$

Jews were relocated to walled-in ghettos $\quad 95 \%$

Cramped, overcrowded living-conditions in the ghetto 30\%

Jews had to sell their possessions and were only allowed a $30 \%$

certain amount of money

It became a necessity to find a job and to own a work certif- $\quad 85 \%$

icate in order to survive in the ghetto

Bartering in order to earn money to buy food/smuggling $\quad 75 \%$

Food shortage, hunger, diseases, starvation, death $\quad 70 \%$

A life in constant fear of being arrested or killed $\quad 25 \%$

$\begin{array}{ll}\text { Random killings of Jews by SS-guards } & 50 \%\end{array}$

Jews collaborating with the Germans by serving as Jewish $40 \%$

Police

$\begin{array}{ll}\text { Jews suffered constant humiliation } & 40 \%\end{array}$

Poles as Jew helpers or as collaborators with the Germans $\quad 100 \%$

$\begin{array}{ll}\text { Deportations to death camps - Treblinka } & 40 \%\end{array}$

The Warsaw Uprising in August $1944 \quad 80 \%$

Source: Prepared by the authors

In contrast to The Pianist, the 14 categories which described the situation in the aftermath of WWII in Germany ${ }^{29}$ in Lore were recognized by an average of $44 \%$ of the participants. Just four categories were described by $50 \%$ or more of the participants. Since Lore depicted the journey of five young siblings from the south to the north of occupied Germany, the categories were often only presented in a few snapshots or dialogues and were, therefore, not as obvious to notice as in "The Pianist" where the protagonist remained in just one location. In addition, only one lesson was devoted to explaining the (political and economic) situation of defeated, occupied and divided Germany after May 1945, since a special focus was on conveying the Holocaust. ${ }^{30}$ The students listened to

\footnotetext{
${ }^{29}$ A wide-spread feeling of despair and hopelessness (25\%), Destruction, poverty, homelessness (75\%), The Allies' hunt for war criminals (25\%), Barter economy, the existence of a black market (13\%), People cared mostly just for themselves (50\%), Displaced people / refugees / children, separated from their parents roamed Germany (19\%), The Holocaust became known to the Germans (38\%), Cases of suicide as a result of the surrender of Germany (19\%), Many Germans denied the Holocaust as propaganda (31\%), Many Germans remained loyal to Hitler and were saddened by his death $(69 \%)$, There was a sense of guilt developing among some Germans (6\%), Germany was divided into occupation zones (81\%), Curfew / restriction of movement (44\%), Lawlessness: rape/murder were common occurrences (44\%) (CHANG; SCHAAR 2020: 238-239)

${ }^{30}$ The Holocaust (teaching content): mass murder of Jews in occupied territories (Poland, Soviet Union) the Babi Jar massacre / the role of SS and SD-Einsatzgruppen / Wannsee Conference decides to eliminate 11 Million Jews in Europe / Reinhard Heydrich, Adolf Eichmann as organizers of the extermination of the Jews / Jewish ghettos in occupied Poland / 1943: Warsaw ghetto uprising / deportation of the Jews to extermination camps: Treblinka, Chelmno, Belzec, Majdanek / Auschwitz-Birkenau as symbol for
} 
SCHAAR, T.; WEN, C.S. - Developing Historical Competency

presentations and watched documentaries; three of the seven films selected for the HFproject were also Holocaust-based films (The Grey Zone, Süskind, The Pianist). Thus, students were much more familiar with facts related to the persecution and extermination of the Jews in World War II than with the situation in post-war Germany.

\section{B) Narrative Analysis}

Most of the NA related film viewing guiding questions focused on key scenes, scenes with great emotional impact and on the filmic representation of events and characters. Selected results are summarized as follows:

Since the HF-project was part of the course BBD3101 and HFs were viewed as a teaching tool and a source of historical information, the BA German students unsurprisingly preferred historical films based on true events (The Grey Zone, Süskind, The Pianis, Der Untergangt) rather than adaptations of a literary text or original screen plays (Jakob der Lügner, Joanna, Lore). Several Students expressed that they felt "close to real events" and a sense of authenticity and "truth" when actors/actresses embody Hitler and other leading Nazis (Goebbels, Himmler, Speer), military leaders (Keitel, Jodl) or female characters such as Eva Braun, Magda Goebbels, Traudl Junge (Hitler's secretary). The "absence" of Hitler as a character in many other World War II films was often criticized. Because the students did not have a really consolidated knowledge about the historical events depicted, they showed preference to HFs which in their perception presented a "bigger picture" 31 (e.g. the killing process of Jews in extermination camps including the death in the gas chamber in The Grey Zone / the descriptive and detailed presentation of the persecution and suffering of Jews in ghettos and in concentration camps in The Pianist, Colette, the last days of Adolf Hitler in the bunker in Der Untergang) rather than narratives which focus on the deeds - fighting, saving, resisting - of individuals or a small group (The Courageous Heart of Irena Sendler, Joanna). ${ }^{32}$ Therefore, many group discussions unrealistically focussed on whether the HFs depicted "the real situation", "the whole situation", "the real attitude towards ..." which often led to selection decisions based on criteria such as: "it does not show the whole situation, only parts" (Miasto44,

\footnotetext{
industrial mass murder by poison gas / inhuman medical experiments by Josef Mengele / liberation of the camps in 1945

${ }^{31}$ However, the survey found that the students were aware, "that a history film can only depict a small part of a greater event" (3.86/I quite agree)

${ }^{32}$ Report of Group 2/2015 states: "We could see that this movie gave all the audience a complete idea of what Holocaust is all about."
} 
SCHAAR, T.; WEN, C.S. - Developing Historical Competency

Brest Fortress); "very little of the Holocaust is shown" (The Courageous Heart of Irena Sendler, Joanna, Ghetto, Jakob der Lügner, Fateless). Students often expressed disappointment in the lack of epic battle scenes in war movies especially with regard to Stalingrad ("depicted are only occasional skirmishes") since they were taught that the battle of Stalingrad was the bloodiest battle in human history with more than a million casualties. However, they appreciated the filmic concept of Katya (a young women in the ruins of Stalingrad) and her five protectors who (as composite characters) stood for all the suffering of the Soviet people in the war and for whom Katya represented Mother Russia, but also a wife, a sister, a lover.

Although most of the BA German students were females, $80 \%$ of them mentioned a great interest in bloody, gory battle scenes (but many of them flinched when Sophie Scholl was led to the execution which is not visible in the film and only the sound of the falling guillotine can be heard). The perception of soldiers in war as anonymous on the one hand and the empathy with the female student Sophie Scholl on the other hand could explain this phenomenon. Other possible explanations might be found in viewing habits and genre preferences (such as Hollywood adaptations of superhero graphic novels and the depicted fight scenes).

In accordance with their cinematic traditions, Malaysian students favour happy endings such as the survival against all odds of Władysław Szpilman in The Pianist and of Colette Cohen and Vili Feld in Colette. Several students expressed sadness about the death of the German soldiers Hans von Witzland and Fritz Reiser (not so much about the Russian Irina who was leading them) in Stalingrad (1993). Although the fate of Sophie Scholl and other resistance fighters was known before the film viewing, students did wish for a different ending. The report of Group 2, cohort 13 shows frustration with the tragic ending in The Grey Zone:

The reason we didn't choose this movie is because the focus of the Jewish Sonderkommando performing their duties while planning to destroy one of the crematoria using the help from Polish people nearby to saving a small girl from being killed. This movie also did not have an upbeat ending. The movie is full of struggles of people in the concentration camp trying to save their lives and other's but at the end of the movie, nobody is alive. This marks their efforts are quite pointless because not even a single live is saved at the end of the movie." (page 8 , unedited)

The scenes which had an emotional impact on the respondents (cohort $13 \& 14$ ) were the execution of Sophie Scholl (Sophie Scholl. Die letzten Tage) / the burning alive of a young Jewish mother and her child in a bus by German soldiers; Russian 
SCHAAR, T.; WEN, C.S. - Developing Historical Competency

"collaborator" Masha being killed by sniper Chranov; the birthday party which Katya's five protectors prepared for her in the ruins of her house; burning Soviet soldiers storming the German defensive positions and the death of Katya's five protectors who called an airstrike on their own position (Stalingrad 2013) / the severe beating of Vili Feld and the forced sterilization of female prisoners (Colette) / Magda Goebbels killing all her young children; a group of boys and girls in Hitler Youth uniform committing suicide instead of becoming prisoners of war (Der Untergang) / a starving elderly Jew licking spilled food from the street; the deportation of Szpilman's family to Treblinka; the random shootings of Jews as well as the graphic scene in which a wheelchair bound Jew is thrown over the balcony to his death by SS troops. Many students were also touched by the scene in which Władysław Szpilman played the piano for the German officer Wilm Hosenfeld, who had caught and identified him as a surviving Jew in destroyed Warsaw. In the coming days, Hosenfeld secured Szpilman's survival (The Pianist).

\section{C) Historical Empathy / Perspective Recognition}

The data analysis leads to the conclusion that most of the respondents when asked to recognize perspectives of characters in HFs, tended to observe just a few character traits and the behaviour as it is depicted on screen. It was then described by lining up a few generalising, often overly positive adjectives or word-groups (for victims and perpetrators alike) without any analysis of beliefs or motivations. The resistance heroine Sophie Scholl for instance was characterized as "brave", "determined”, “intelligent”, “selfless", "caring", "loyal to her brother", "calm during interrogation”, "a resistance fighter without fear and regret" while her interrogator Inspector Robert Mohr was seen as "strict", "disciplined", "law abiding”, "a man of principle", "a good inspector”, “persistent”, "loyal to Hitler", "not cruel". Sophie Scholl's Christian up-bringing and belief system, her knowledge of the "euthanasia programme" ${ }^{33}$ and the mass murder of civilians by German troops in the Soviet Union (witnessed by her brother and his friends at the Eastern front) which motivated her to risk her young life by joining her brother's (non-violent) resistance group "Weiße Rose” was left unexplained as well as Mohr's gratitude towards Hitler for creating "law and order" in Germany after the political and economic turmoil

\footnotetext{
33 "T4 Program, also called T4 Euthanasia Program, Nazi German effort - framed as a euthanasia program - to kill incurably ill, physically or mentally disabled, emotionally distraught, and elderly people..." (https://www.britannica.com/event/T4-Program)
} 
SCHAAR, T.; WEN, C.S. - Developing Historical Competency

and the suffering of many Germans during the Weimar Republic. Several students developed a rather "positive" view on Adolf Hitler, due to scenes from Der Untergang:

N. added that this movie shows who Hitler really was. Actually, Hitler was such a kind and caring person, and know how to comfort the person he is close to. Viewer can see many scenes that portrayed this noble character as he cares about Traudl where he gives permission and also convinced her to leave Berlin through the secret place to save her life. He also loves kids which in the movie showed his kindness and loveliness towards Goebbel's children. (Group report IV/1, p 11, unedited)

Students also expressed empathy for Hitler's feelings of disappointment in Nazi leaders such as Göring, Himmler and Speer and Hitler's perceived betrayal by his generals. Many BA German students seem to cherish loyalty and expressed respect towards depicted leaders: to resistance fighters, Wehrmacht and SS-officers and Nazi party leaders alike (depending on the origin of movies and the protagonists). Brave and patriotic characters - German soldiers (Stalingrad), Soviet soldiers (The Brest Fortress, Stalingrad) ${ }^{34}$, Polish civilians during the Warsaw uprising (Miasto 44), Jew helpers (The Pianist), resistance fighters (Sophie and Hans Scholl) - were greatly admired; above all courageous Hitler Youth members who fought against all-odds in the last battles in 1945 (e.g. the composite character "Peter Kranz" in Der Untergang, who destroyed 2 Soviet tanks). ${ }^{35}$ Fulfillment of duty, even if it means killing innocent people (SS-Oberscharführer Erich Mußfeldt, in charge of the gas chamber and crematorium IV in Auschwitz), was also evaluated as a positive character trait by several students (The Grey Zone). Wulff refers to a psychological phenomenon that could explain this simplified perception by students:

In der Sozialpsychologie gibt es einen Nachweis des so genannten Halo-Effektes, also der Tendenz von Beobachtern, andere Personen weitgehend einheitlich wahrzunehmen. Das bedeutet, dass ein Beobachter, der eine andere Person im Hinblick auf ein Merkmal positiv einschätzt, dazu neigt, diese Person auch im Hinblick auf andere, von ihm nicht beurteilbare Aspekte hin positiv zu erleben.

[In social psychology there is evidence of the so-called halo effect, i.e. the tendency of observers to perceive other people in a largely uniform way. This means that an observer who assesses another person positively with regard to one characteristic tends to experience this person positively with regard to other aspects that he cannot assess.] (2006: 50) (translated with deepL translator)

In contrast, Germans, who fought as soldiers in the Soviet army (Ich war 19), Wehrmacht generals or officers who capitulated or Wehrmacht deserters were regarded

\footnotetext{
${ }^{34}$ The individual assignments suggested that BA German students sympathize more with the fate of German soldiers than with Soviet soldiers (even in the Russian movie "Stalingrad", 2013) by completely disregarding the fact that the Germans were the aggressors. A possible explanation might be the course subject itself (German history).

${ }^{35}$ Group report IV/1, page 11 mentioned: "S. said that this movie very much touched her heart because they were all fighting until the end of the war even, they do not have many chances and hopes." (unedited)
}

Pandaemonium, São Paulo, v. 25, n. 45, jan.-abr. 2022, p. 29-65 
SCHAAR, T.; WEN, C.S. - Developing Historical Competency

as being disloyal to Hitler and to Germany and therefore condemned as traitors by several students. ${ }^{36}$

In Holocaust-based movies students often struggled with the moral "grey zone" of many characters (e.g. the Jewish members of the "Sonderkommando" as part of the extermination mechanism in Auschwitz-Birkenau; Jewish doctor Miklós Nyiszli, who volunteered to assist Josef Mengele in his inhumane experiments on inmates in Auschwitz, The Grey Zone). Jews, who collaborated with the German authorities just to survive another day were simply regarded as traitors to their own people without trying to consider what motivated their (often desperate) actions (Süskind, Schindler's List, The Pianist, Colette). Walter Süskind was criticized as being "irresponsible" for putting his own children in danger while trying to save other Jewish children and for supporting the SSauthorities in deporting Jewish adults. Süskind's role in the Jewish council and his pragmatic "friendship" with SS-Hauptsturmführer Ferdinand aus der Fünten (who as "head of the Central Office for Jewish Emigration" was responsible for the deportation of Jews in Amsterdam to German extermination camps) which many Jews regarded as collaboration with the Nazis but which enabled him to save hundreds of Jewish children was not fully understood. Students - in the knowledge of the extermination of the Jews - characterized Süskind as being naïve for not knowing the fate of the deported Jews. Furthermore, students showed empathy for Ferdinand aus der Fünten by narrowing their characteristic of him to the description of his feeling of loneliness, his grief over the death of his brother at the Eastern front and his valued friendship with Süskind, without even mentioning his cowardice and his involvement in war crimes and the death of thousands of Jews.

Movie characters especially documented characters were regarded by many respondents as conveyers of absolute historical truth. In the after-viewing discussion of "The Germans at War", the lecturer asked to describe the situation in Germany in early 1943. Students repeated Sophie Scholl's argument during her interrogation, in which she claimed that most of the German people were tired of the war and wanted peace. By pointing out the historical inaccuracy of Scholl's perception, several students indicated

\footnotetext{
${ }^{36}$ Although the movie "Ich war 19" gives a great insight into the complex and confusing situation in Nazi Germany in April 1945, the movie was rejected by the group members since the protagonist Gregor Schwarz - an exiled German Communist who returned to Germany as a soldier in the Soviet army - was regarded as having betrayed his country!
}

Pandaemonium, São Paulo, v. 25, n. 45, jan.-abr. 2022, p. 29-65 
SCHAAR, T.; WEN, C.S. - Developing Historical Competency

disappointment (in Sophie Scholl and in the movie as well!). ${ }^{37}$ Ashby and Lee (1987, cited in BARTON; LEVSTIK 2004: 209) outlined "five levels of empathetic understanding". Based on the individual assignments of the participants of the World War II-HF-project (cohort 14), it must be noted that $57 \%$ of the participants need to be classified in the lower levels in $\mathrm{PR}^{38}$, while $24 \%$ reached a mid-level ${ }^{39}$ and only $19 \%$ can be assigned to the highest levels. ${ }^{40}$

\section{Conclusions}

Overall, it can be estimated that the implementation of historical films in the BBD3101 classroom - despite all the described suboptimal pre-conditions, the intellectual adjustments to the medium feature film as previously unknown teaching tool, time restrictions and shortcomings in the preparation for the development of the HLC - showed predominantly satisfactory results and the recorded assessments by the students were mostly positive appraisals for the selected HFs as well as for the project's format. ${ }^{41}$ Students initially did not question the filmic interpretations and regarded HFs as "a history book with moving images" (edutainment) instead of a "document" which like any historical source needed to be thoroughly investigated, analysed, discussed and critiqued. When given the necessary guidance and tools (HLC, viewing questions), however, they were able to (more) critically examine and actively deal with content, narrative and perspectives presented in the films. Passive spectators turned into motivated, interested, actively involved inquirers. Most participants found history films as teaching tools particularly engaging and useful for contextualization, as opportunities for in-depth discussions and for study purposes. HFs were described as entertaining, motivating, thought-provoking and

\footnotetext{
${ }^{37}$ It must also be noted that many students had problems to differentiate and instead preferred to generalize statements (the Germans / all Germans / the Jews ...), which must be accredited to shortcomings of the Malaysian education system.

${ }^{38}$ Level 2: ... students understand people's action with reference to generalized stereotypes; they explain actions ..., but without any attempt to place actions in a specific historical context... 12 (MF 2, 3, 4, 6, 7, 9, $10,12, \mathrm{CF} 2,5, \mathrm{MM} 2, \mathrm{CM} 2) /$

${ }^{39}$ Level 3: ... students understand actions with reference to the specific situation in which people find themselves but still fail to distinguish between how we would see the situation in the present and how contemporaries saw it...5 (MF5, 8, 11, CF 1, 4)

${ }^{40}$ Level 4: ... students understand the specific situations in which people found themselves and recognize that they would not necessarily have characterized those situations in the same terms we would, because their beliefs, goals, and values were different than ours; however, these students tend to focus narrowly on specific situations ...2 (MM1, CM1) / Level 5: ... students place actions within the broader context of other differences in beliefs, values, and material conditions within historical societies ... 2 (MF1, CF 3)

${ }^{41}$ Criticism of the project mostly revolved around the demand for more guidance provided by the lecturer in the film selection stage and for longer in-depth discussions as well as time management issues.
} 
SCHAAR, T.; WEN, C.S. - Developing Historical Competency

intellectually stimulating but also as emotionally testing. The movies which elicited the strongest emotional responses but also proved to be rather challenging when analysing HE/PR were the Holocaust-themed The Grey Zone and The Pianist.

While the answers given to questions related to CK and NA revealed promising results, the participants showed (explainable) shortcomings in the examination of historical characters and the motivations for their actions (HE/PR). ${ }^{42}$ Besides the already mentioned halo effect and its overly positive and rather one-dimensional perception of complex characters, other reasons why the results on HE/PR were below the authors' expectations must be mentioned. The HF-project was the first time that the BA students watched movies in an academic setting accompanied by guiding questions. The majority watched the movies just once, while the lecturer is very familiar with contents, characters and narratives. Being inexperienced in analyzing HF and taking notes while watching (or trying to remember afterward), much information got unnoticed and were therefore not outlined in the individual assignments.

Barton \& Levstik regard PR as an "intellectual tool" and identified five elements that need to be developed in the history classroom for a more targeted preparation of the perspective analysis: “a sense of 'otherness', shared 'normalcy', historical contextualization, differentiation of perspectives, and contextualization of the present (2004: 209-210). The importance of key factors such as time ("a lengthy process"), "practice and careful mentoring" in the development of PR "grounded in an ever-deepening historical knowledge base" is especially emphasized (BARTON; LEVSTIK 2004: 223). The limited time available for the lecturer to teach the historical competencies allowed only a superficial perspective recognition of filmic characters.

There was great approval for the statements that the film-based assignments "helped me to develop critical thinking" (4.51), "increased my ability for team-work" (4.47) and "increased my interest in history" (4.15). It can be concluded that the BA students enhanced their critical multi-literacy skills and developed a higher level of competency in CK; and as the project progressed a (slightly) higher level of HE/PR as well. They became more confident in being able to "read" HFs and in expressing their

\footnotetext{
42 "Meaningful history education requires the ability to understand the perspectives of different peoples in the past. Otherwise, past perspectives become undifferentiated and highly simplified, resulting in an unsophisticated reading of events in terms of heroes and villains, right and wrong, all judged by how well they fit with present-day perspectives that past generations might not have valued or even recognized. Historical empathy is an emotional and psychological competency that requires the viewer to recognize and respect potentially foreign perspectives." (METZGER 2007: 71)
} 
SCHAAR, T.; WEN, C.S. - Developing Historical Competency

perspectives in writing and in after-viewing discussions. Although, a greater number of students initially had difficulties to cope with film-based education, many (not all) very much appreciated the different approach and format of teaching history in BBD3101 by implementing HFs constructively for inquiry-based learning activities compared to the teaching methods they were used to from their respective high schools. Therefore, the students "totally agreed" that "the lecturer should include more historical movies in history class" (4.67) as well as "more documentaries" (3.76/I quite agree).

\section{Bibliographic references}

ABCD Thesen zur Rolle der Landeskunde im Deutschunterricht. IIDV Rundbrief, v. 45, 15-18, 1990.

ABD RAHMAN, Nik Hassan Shuhaimi Nik; Kospin, Siti Masni; RAUB, Zalehar. Sejarah tingkatan 4: buku teks. Kuala Lumpur: Dewan Bahasa Dan Pustaka, 2002.

ADAM, Ramlah binti; YACOB, Shakila Parween binti; SAMURI, Abdul Hakim bin. Sejarah tingkatan 5: buku teks. Kuala Lumpur: Dewan Bahasa Dan Pustaka, 2002.

ARENDT, Christine. Geschichte diversifizieren und lebendig werden lassen - letzte Kriegsjahre, Ende des Zweiten Weltkriegs und Nachkriegszeit im DaF-Unterricht. Zeitschrift für interkulturellen Fremdsprachenunterricht, v. 24, n. 2, 2019, 339-376.

BADSTÜBNER-KIZIK, Camilla. Kulturelles Gedächtnis und Erinnerungsorte im Kontext Deutsch als Fremdsprache. Zeitschrift für Interkulturellen Fremdsprachenunterricht, v. 25, n. 1, 2020, 649-675. Available at: https://tujournals.ulb.tu-darmstadt.de/index.php/zif/article/view/1028/1025 (13/08/2020).

Barton, Keith. C.; LevstiK, Linda S. Teaching History for the Common Good. New Jersey: Lawrence Erlbaum Associates Inc., 2004.

BBD3101 Kajian Sejarah Jerman, BA German, English, Final Version: 2011.

BELLINO, Michelle. Historical Understanding and Media Literacy: A Dispositional Alignment. International Journal of Social Education, v. 23, 2008, 99-117.

BIECHELE, Barbara. Verstehen braucht Sehen: entdeckendes Lernen mit Spielfilm im Unterricht Deutsch als Fremdsprache. In: WelKe, Tina; FAISTAUER, Renate (ed.). Lust auf Film heißt Lust auf Lernen. Der Einsatz des Mediums Film im Unterricht Deutsch als Fremdsprache. Wien: Praesens, 2010, 13-32.

BINZ, Roland. Der ganz große Traum. Zeitgeschichte-online. Available at: https://zeitgeschichteonline.de/film/der-ganz-grosse-traum (06/07/2020).

BRANDI, Marie-Luise. Video im Deutschunterricht. Eine Übungstypologie zur Arbeit mit fiktionalen und dokumentarischen Filmsequenzen. Fernstudieneinheit 13. Berlin: Langenscheidt, 1996.

BROWN, Tony. Using film in teaching and learning about changing societies. International Journal of Lifelong Education, v. 30, n. 2, 2011, 233-247.

BYERS, Richard. "Reel Germans": Teaching German (And World) History with Film. World History Connected, v. 7, n. 1, 2010. Available at: https://worldhistoryconnected.press.uillinois.edu/7.1/byers.html (30/11/2020).

CHANG, Shi Wen; SCHAAR, Torsten. A Case Study: Exploring Historical Literacy through Historical Feature Films among BA German Students (Universiti Putra Malaysia). In:

Pandaemonium, São Paulo, v. 25, n. 45, jan.-abr. 2022, p. 29-65 
SCHAAR, T.; WEN, C.S. - Developing Historical Competency

SchaAR, Torsten; Altal, Mahasen; Chang, Shi Wen (ed.). Fokus DaF/DaZ. Gegenwärtige Tendenzen in Forschung und Lehre. Münster: LIT Verlag, 2020, 229-244.

CHONG, Chee-Huay; Yeo, Kee-Jiar. Why Students Fail in History: A Minor Case Study in Malaysia and Solutions from Cognitive Psychology Perspective. Mediterranean Journal of Social Sciences, v. 7, n. 1, 2016, 517-526.

CHUDAK, Sebastian. Geschichte erleben im DaF-Unterricht - aber wie? Zu den Zielen und Möglichkeiten der Förderung von Erinnerungserlebnissen durch den Einsatz von Filmen (am Beispiel des Kurzspielfilms „Spielzeugland“). Glottodidactica, v. XLII, n. 2, 2015, 133151.

DING, Susanne. The European Commission's Approach to Media Literacy. LIVINGSTONE, Sonia (ed.). Media literacy: Ambitions, policies and measures. London: LSE, 2011, 5-7.

DonNelly, Debra. Teaching History Using Feature Films: Practitioner Acuity and Cognitive Neuroscientific Validation. History Education Research Journal, v. 12, n.1, 2013, 16-27.

DONNELLY, Debra. Using feature films in teaching historical understanding: Research and practice. Agora, v. 49, n. 1, 2014, 4-12.

FAISTAUER, Renate. Prinzipien im Sprachunterricht $=$ Prinzipien für die Arbeit mit Filmen im Sprachunterricht?! In: WeLKE, Tina; FAISTAUER, Renate (ed.). Lust auf Film heißt Lust auf Lernen. Der Einsatz des Mediums Film im Unterricht Deutsch als Fremdsprache. Wien: Praesens, 2010, 33-45.

FRÖHLICH, Margit; SCHNEIDER, Christian; VISARIUS, Karsten. Das Böse im Blick. Die Gegenwart des Nationalsozialismus im Film. München: edition text + kritik, 2007, 7-12.

GERMANS etched in our history. The Star, 13 Oct. 2012. Available at: https://www.thestar.com.my/news/community/2012/10/13/germans-etched-in-our-history/ (21/09/2020).

GÖDECKE, Christian. Der Mann, der die „englische Krankheit“ einschleppte. Der Spiegel, 18 Feb. 2011. Fußballanfänge in Deutschland. Available at: http://www.spiegel.de/einestages/fussballanfaenge-in-deutschland-a-947074.html (31/07/2019).

Johdi Salleh, Mohamad; Mohamad, Baharom; Ambotang, Abdul Said. The Significant of History Curriculum in the Development of Active Citizen: A Critical Analysis of the ICSS History. International Journal of Scientific and Research Publications, v. 3, n. 9, 2013, 1-8.

KHOO, Salma Nasution. More than Merchants. A History of the German-speaking Community in Penang, 1800s-1940s. Penang: Areca Books, 2006.

KING, Jane. Using DVD feature film in the EFL classroom. Computer Assisted Language Learning, v. 15, n. 5, 2002, 509-523.

KOREIK, Uwe. Deutschlandstudien und deutsche Geschichte. Die deutsche Geschichte im Rahmen des Landeskundeunterrichts für Deutsch als Fremdsprache. Baltmannsweiler: Schneider Verlag Hohengehren, 1995.

KOREIK, Uwe. Landeskunde, Geschichte und ,Erinnerungsorte“ im Fremdsprachenunterricht. In: BADSTÜBNER-KIZIK, Camilla; HILlE, Almut (ed.). Kulturelles Gedächtnis und Erinnerungsorte im hochschuldidaktischen Kontext. Frankfurt am Main: Peter Lang, 2015, 1536.

KOREIK, Uwe; RochE, Jörg. Zum Konzept der „Erinnerungsorte“ in der Landeskunde für Deutsch als Fremdsprache - eine Einführung. In: RocHE, Jörg; RöHLING, Jürgen (ed.). Erinnerungsorte und Erinnerungskulturen. Konzepte und Perspektiven für die Sprachund Kulturvermittlung. Baltmannsweiler: Schneider Verlag Hohengehren, 2014, 9-27.

Marcus, Alan S.; MetzGer, Scott A.; PAXTon, Richard J.; StOdDard, Jeremy D. Teaching History with Film. Strategies for Secondary Social Studies. London: Routledge, 2010.

MetzGer, Scott A. Pedagogy and the Historical Feature Film: Toward Historical Literacy. Film \& History: An Interdisciplinary Journal of Film and Television Studies, v. 37, n. 2, 2007, 67-75. 
SCHAAR, T.; WEN, C.S. - Developing Historical Competency

Rosenstone, Robert A. History on Film. Film on History. London: Routledge, 2012.

Rosenstone, Robert A. The Historical Film as Real History. Film-Historia, v. V, n. 1, 1995, 523.

SCHAAR, Torsten; SCHÄFER, Bernd; SELKE, Raimond. World War II in Europe in Selected European Feature Films, 2010-2013. In: MASON, Richard; SUCHOPLES, Jaroslav (ed.). Representations of War in Films and Novels. Frankfurt am Main: Peter Lang GmbH, 2015, $127-$ 178.

SCHMIDT, Sabine; SCHMIDT, Karin. Erinnerungsorte. Deutsche Geschichte im DaF-Unterricht. Materialien und Kopiervorlagen. Berlin: Cornelsen, 2016.

SCHWERDTFEGER, Inge Christine. Sehen und Verstehen. Zur Arbeit mit Film und Video im Fremdsprachenunterricht. Berlin: Langenscheidt, 1989.

VETRIE, Michael. Using Film to Increase Literacy Skills. The English Journal, v. 93, n. 3, 2004, 39-45.

WOELDERS, Adam. „It Makes You Think More When You Watch Things“: Scaffolding for Historical Inquiry Using Film in the Middle School Classroom. The Social Studies, v. 98, n. 4, 2007, 145-152.

WOELDERS, Adam. Using Film to Conduct Historical Inquiry with Middle School Students. The History Teacher, v. 40, n. 3, 2007, 363-395.

WulfF, Hans J. Attribution, Konsistenz, Charakter Probleme der Wahrnehmung abgebildeter Personen. Montage/AV, 2006, 45-62.

Recebido em 06 de janeiro de 2021 Aceito em 21 de abril de 2021 